\title{
Öğretmenlerin ve Öğretmen Adaylarının Öğretmenlik Mesleği Genel Yeterliklerine İlişkin Öz Değerlendirmeleri ${ }^{1}$
}

Mehmet Koçyiğit²

Type/Tür:

Research/Araştırma

Received/Geliş Tarihi:

November 27/ 27 Kasim 2019

Accepted/Kabul Tarihi: June

22/ 22 Haziran 2020

Page numbers/Sayfa No: 774-

799

Corresponding

Author/İletişimden Sorumlu

Yazar: eegmir@aku.edu.tr

\section{$\checkmark$ iThenticate}

This paper was checked for plagiarism using iThenticate during the preview process and before publication. / $\mathrm{Bu}$ çalışma ön inceleme sürecinde ve yayımlanmadan önce iThenticate yazılımı ile taranmıştır.

Copyright $\left({ }^{\circ} 2017\right.$ by Cumhuriyet University, Faculty of Education. All rights reserved.

\author{
Cahit Erdem ${ }^{3}$
}

Eray Ĕgmir 4

\section{Öz}

Bu araştırmada öğretmenlerin ve öğretmen adaylarının “Öğretmenlik Mesleği Genel Yeterliklerine" ilişkin kendilerini nasıl değerlendirdiklerinin belirlenmesi amaçlanmaktadır. Bunun yanı sıra, öğretmen ve öğretmen adaylarının bu değerlendirmeleri arasında anlamlı bir farklılık olup olmadığı ve öğretmen ve öğretmen adaylarının değerlendirmelerinin birtakım değişkenlere göre anlamlı olarak farklılaşıp farklılaşmadığı da çalışmada incelenmiştir. Bu amaçla saha taraması modelinde desenlenen bu araştırmada bir devlet üniversitesinin eğitim fakültesinin birinci ve dördüncü sınıflarında öğrenim gören 275 öğretmen adayından ve aynı ilde farklı okul türlerinde görev yapan 116 öğretmenden veri toplanmıştır. Verilerin toplanması amacıyla Millî Eğitim Bakanlığı tarafından yayımlanan “Öğretmenlik Mesleği Genel Yeterlikleri'nde yer alan maddeler kullanılarak bir ölçme aracı geliştirilmiş ve aracın geçerlik ve güvenirlik çalışmaları yapılmıştır. Çalışmada öğretmenlerin ve öğretmen adaylarının mesleki yeterliklere ilişkin algılarının yüksek düzeyde olduğu, öğretmenlerin mesleki yeterliklere ilişkin öz değerlendirmelerinin "öğrenciye yaklaşım" boyutu haricinde öğretmen adaylarına göre anlamlı düzeyde daha yüksek olduğu, öğretmenlerin yeterlik algılarının branş, görev yapılan okul türü ve eğitim düzeyi değişkenine göre farklılaşmazken çeşitli faktörlerde cinsiyet ve kıdem değişkenlerine göre farklılaştığı, ve öğretmen adaylarının yeterlik algılarının cinsiyet değişkenine göre farklılaşmazken, çeşitli faktörlerde sınıf düzeyi ve program değişkenine göre farklılaştığı bulgularına ulaşılmıştır. 2017 yılında güncellenen öğretmen yeterliklerinin öğretmenlik kariyerinde önemli bir değişken olarak planlandığı ve güncel yeterliklerle ilgili çalışmaların sınırlı olduğu düşünüldügüünde araştırmanın alanyazına katkı sunması beklenmektedir.

Anahtar Kelimeler: Öğretmenlik mesleği, öğretmen adayları, öğretmen yeterlikleri, öğretmenlik mesleği genel yeterlikleri, öz-değerlendirme.

\section{Suggested APA Citation/Önerilen APA Atıf Biçimi:}

Koçyiğit, M., Erdem, C. \& Eğmir, E. (2020). Öğretmenlerin ve öğretmen adaylarının öğretmenlik mesleği genel yeterliklerine ilişkin öz değerlendirmeleri. Cumhuriyet International Journal of Education, 9(3), 774-799. http://dx.doi.org/10.30703/cije.651639

\footnotetext{
${ }^{1}$ Bu çalışmanın etik açıdan bir sakınca taşımadığı Afyon Kocatepe Üniversitesi Sosyal ve Beşeri Bilimler Bilimsel Araştırma ve Yayın Etiğ Kurulu'nun almış olduğu 11.01.2019 tarih ve 31731878-050.01.04 sayılı karar ile tespit edilmiştir.

2 Dr. Öğr. Üyesi, Afyon Kocatepe Üniversitesi Eğitim Fakültesi, Eğitim Bilimleri Bölümü, Afyonkarahisar/Türkiye

Asst. Prof. Dr., Afyon Kocatepe University Faculty of Education, Department of Educational Sciences, Afyonkarahisar/Turkey e-mail: mkocyigit@aku.ed.tr ORCID ID: orcid.org/0000-0002-1836-844X

${ }^{3}$ Dr. Öğr. Üyesi, Afyon Kocatepe Üniversitesi Eğitim Fakültesi, Yabancı Diller Eğitimi Bölümü, Afyonkarahisar/Türkiye

Asst. Prof. Dr., Afyon Kocatepe University Faculty of Education, Department of Foreign Languages Education, Afyonkarahisar/Turkey e-mail: cahiterdem@gmail.com ORCID ID: orcid.org/0000-0001-6988-8122

${ }^{4}$ Dr. Öğr. Üyesi, Afyon Kocatepe Üniversitesi Eğitim Fakültesi, Eğitim Bilimleri Bölümü, Afyonkarahisar/Türkiye

Asst. Prof. Dr., Afyon Kocatepe University Faculty of Education, Department of Educational Sciences, Afyonkarahisar/Turkey e-mail: eegmir@aku.ed.tr ORCID ID: orcid.org/0000-0003-3054-1011
} 


\title{
Self-Evaluations of Teachers and Pre-Service Teachers with respect to Their General Competencies for Teaching Profession
}

\begin{abstract}
This study aims to put forward how teachers and pre-service teachers evaluate themselves regarding "General Competencies for Teaching Profession". In addition, the present study sets out to examine whether there is a significant difference between teachers' and pre-service teachers' self-evaluations and whether their evaluation scores differed significantly in terms of various variables. To this end, in this survey design study, data were collected from 275 freshman and senior pre-service teachers at a state university in Turkey and 116 teachers working at different types of schools in the same province through an instrument developed by the researchers based on "General Competencies for Teaching Profession" introduced by Turkish Ministry of National Education. Validity and reliability analyses were carried out for the instrument. Some of the findings include: teachers and pre-service teachers have a high level perception regarding teacher competencies; teachers' scores are significantly higher than preservice teachers' except for "Approach to Student" dimension; teachers' competency perceptions differ significantly by gender and seniority in some dimensions but not by major, school type or education level; pre-service teachers' competency perceptions do differ by gender but differ by grade level and department variables in some dimensions. Considering that the teacher competencies, revised in 2017, are planned as an important variable in teaching career in Turkey and the limited research on this issue, this study is expected to contribute to the literature.
\end{abstract}

Keywords: Teaching profession, pre-service teachers, teacher competencies, general competencies for teaching profession, self-evaluation.

\section{Giriş}

Bireylerin hayatın her alanında sahip olması gereken yeterlikler, içinde bulunulan zaman dilimine göre değişiklik göstermektedir. Özellikle 21. yüzyılda yoğun olarak yaşanan değişim ve dönüşümler bireylerin sahip olması gereken yeterlikleri de etkilemiştir. Bireylerin ihtiyaç duydukları yeterlikleri kazanmasında en önemli rol ise okullara ve dolayısıyla da öğretmenlere düşmektedir. Bu yönüyle öğretmenlerin etkili bir öğretim yapabilmek için çeşitli yeterliklere sahip olması gerektiği açıktır; ancak durum öğretimsel yeterliklerle sınırlı değildir. Öğretmenler aynı zamanda öğrencilerin örnek aldığ1 birer yurttaştır. Öğretmenler öğrencilere çeşitli bilgileri aktarmanın yanı sıra düşünceleri, duyuşsal tepkileri, değer ve alışkanlıkları ile öğrencileri etkilerler; bu nedenle nitelikli insan gücüne erişebilmek ancak nitelikli öğretmenler aracılığ1 ile mümkündür (Erişti, 2008).

Milli Eğitim Bakanlığı (MEB) (2017), öğretmen yeterliklerini “öğretmenlerin, öğretmenlik mesleğini etkili ve verimli bir biçimde yerine getirebilmek için sahip olmaları gereken bilgi, beceri ve tutumlar" olarak tanımlamaktadır. Öğretmen yeterlikleri alan yazındaki çalışmalarda (Coşkun, Özer ve Tiryaki, 2010; Dilci ve Yıldız, 2012; Kahramanoğlu ve Ay, 2013) ve resmi dokümanlarda çoğunlukla alan bilgisi, pedagojik bilgi ve genel kültür bilgisi olarak gruplandırılmaktadır; fakat farklı alanlarda yeterliklerin ön plana çıtı̆̆ı sınıflamalar da mevcuttur. Alan yeterliği, araştırma yeterliği, eğitim programı yeterliği, yaşam boyu öğrenme yeterliği, sosyalkültürel yeterlikler, duygusal yeterlikler, bilgi ve iletişim teknolojileri yeterliği ve çevresel yeterlikler bu yeterlik alanları arasında sayılabilir (Selvi, 2010). 
Öğretmen yeterlikleri konusunda üzerinde uzlaşılan kimi evrensel ilkeler belirlenebilse de öğretmen yeterlikleri tarihsel süreç içinde çağın ihtiyaçları ve eğitim felsefesine dayalı olarak her ülkenin kendi koşulları bağlamında belirlenmeli ve süreç içinde güncellenmelidir (MEB, 2017). Öğretmenlik mesleği genel yeterliklerinin Türkiye'de geçmişi şu şekilde özetlenebilir: 1739 Sayılı Milli Eğitim Temel Kanunu (METK) öğretmenliği bir uzmanlık mesleği olarak tanımlamış, öğretmenlerin sahip olmaları gereken nitelikleri genel kültür, özel alan eğitimi ve pedagojik formasyon sacayağına oturtmuş ve bu nitelikleri belirleme yetkisi Öğretmen Yetiştirme ve Geliştirme Genel Müdürlügüne verilmiştir. Bu kapsamda ilk olarak 1997 yılında kurulan öğretmen yetiştirme ve istihdamı ile ilgili birimler arasında koordinasyonu sağlamak üzere Öğretmen Yetiştirme Türk Milli Komitesi kurulmuştur. Daha sonra 1998-1999 öğretim yılında YÖK ve Dünya Bankası “Milli Eğitimi Geliştirme Projesi Hizmet Öncesi Öğretmen Eğitimi" gerçekleştirilmiş ve öğretmen eğitiminde bir akreditasyon modeli oluşturulmuştur. Bu kapsamda, "konu alanı ve alan eğitimine ilişkin yeterlikler", "öğretme-öğrenme sürecine ilişkin yeterlikler", "öğrencilerin öğrenmelerini izleme, değerlendirme ve kayıt tutmaya ilişkin yeterlikler", ve "tamamlayıcı mesleki yeterlikler" başlıkları altında öğretmenlik meslekî yeterlikleri belirlenmiştir (Erişti, 2008; Günçer, 1999; MEB, 2006; MEB, 2017).

Bu gelişmelere paralel olarak, 1999 yılında MEB bünyesinde “Öğretmen Yeterlikleri Komisyonu" kurulmuş ve 2002 yılında "Öğretmen Yeterlilikleri" belgesini yayımlamıştır. Diğer yandan, 2000 yılında Avrupa Birliği Komisyonu ve Türkiye Cumhuriyeti arasında yapılan anlaşma çerçevesinde öğretmen eğitimini de içeren “Temel Eğitime Destek Projesi "gerçekleştirilmiştir. Bu proje kapsamında 2006 yılında 6 ana yeterlik alanı (kişisel ve mesleki değerler-mesleki gelişim, öğrenciyi tanıma, öğrenme ve öğretme süreci, öğrenmeyi, gelişimi izleme ve değerlendirme, okul, aile ve toplum ilişkileri ve program ve içerik bilgisi), 31 alt yeterlik ve 233 performans göstergesinden oluşan “Öğretmenlik Mesleği Genel Yeterlikleri” kabul edilmiştir (MEB, 2006).

2008 yılında ilköğretim kademesindeki öğretmenlere yönelik 14 alanda, 2011 yılında ise ortaöğretim kademesinin öğretmenlerine yönelik sekiz alanda özel alan yeterlikleri belirlenmiştir. Diğer yandan, 2011 yılında Bologna süreci kapsamında "Yükseköğretim Yeterlikler Çerçevesi Temel Alan Yeterlikleri" kabul edilmiş ve 2015 yılında Avrupa Yeterlikler Çerçevesine uyum bağlamında “Türkiye Yeterlikler Çerçevesi" oluşturulmuştur. Ulusal belgeler bağlaminda ise öğretmen yeterliklerinin belirlenmesi ve güncellenmesi hususu 10. Kalkınma Planında, 2015-2019 MEB Stratejik Planında, 2017 tarihli “Öğretmen Strateji Belgesi”nde ve 19. Milli Eğitim Şurası'nda yer almıştır. Bu belgeler doğrultusunda 2017 yılında Öğretmenlik Mesleği Genel Yeterlikleri güncellenmiştir. Bu çalışma kapsamında, öğretmenlik mesleği genel yeterlikleri, mesleki bilgi, mesleki beceri ve tutum ve değerler bileşenlerinden oluşan üç yeterlik alanı, 11 yeterlik ve 65 göstergeden meydana gelmektedir. Diğer yandan, yapılan bu çalışmaya öğretmenlik özel alan yeterlikleri dâhil edilmemiştir (MEB, 2017).

2017 y1lında kabul edilen güncel yeterlikler doğrultusunda hizmet öncesi öğretmen yetiştirme sürecine ilişkin olarak 2018 yılında öğretmen yetiştirme lisans programları güncellenmiştir. 3 Kasım 2019 tarihinde yayınlanan “2020 Yilı Cumhurbaşkanlığı Yıllık Programı"nda bu yıl içerisinde kariyer basamakları 
sistemine geçilmesi (Resmi Gazete, 2019) ve bahsedilen diğer alanlarda da adımlar atılması planlanmaktadır. Bütün eğitim ekosistemini etkilemesi beklenen bu yeterliklerin üzerinde önemle durulması gerekmektedir.

Öğretmenlerin sahip oldukları mesleki genel yeterliklerin farkında olması, buna dayalı olarak eksiklerin belirlenerek kişisel gelişimlerinin sağlanması önem taşımaktadır. Öğretmenlik mesleği genel yeterliklerinde (MEB, 2017) de öğretmenlerin kendilerinden beklenen yeterliklere ilişkin öz değerlendirme yaparak kişisel ve mesleki gelişimlerini planlamaları beklenmektedir. Diğer yandan, bu yeterliklerin mesleğe atanma, aday öğretmenlik süreci ve sonrasında mesleki gelişim aşamalarında kullanılacağı düşünüldüğünde öğretmenlerin mesleki yeterlik düzeylerinin belirlenmesi daha çok önem arz etmektedir. Konunun bir diğer paydaş1 olan eğitim fakültelerinde öğrenim görmekte olan öğretmen adaylarının da bu genel yeterlikler hakkında bilgi sahibi olması, kendilerini değerlendirmeleri ve bu değerlendirmelere dayalı olarak öğrenim hayatında kişisel gelişimlerini planlamaları gerekmektedir. Bu nedenlerle, hizmet sürecinde bulunan öğretmenler ile hizmet öncesi süreçte bulunan öğretmen adaylarının öğretmenlik mesleki genel yeterliklerine ilişkin öz değerlendirmelerinin yapıldığı araştırmalara ihtiyaç bulunmaktadır. Alanyazında bu yönde yapılan çalışmalar bulunmakla birlikte bu çalışmaların büyük bir kısmı güncel öğretmenlik mesleği genel yeterlikleri ile değil çalışmaların yapıldığ1 tarihlerdeki yeterlikler ile ilişkilidir (Bulut, 2014; Coşkun, Özer ve Tiryaki, 2010; Çubukçu, 2010; Kahramanoğlu ve Ay, 2013; Kararmaz ve Arslan, 2014; Keskin, 2013; Numanoğlu ve Bayır, 2009; Özer ve Gelen, 2008; Taşar, 2012; Taşgın ve Sönmez, 2013; Yalçın İncik ve Akay, 2015; Yeşilyurt, 2011).

2023 Vizyon Belgesi kapsaminda eğitimde sistematik değişim ve dönüşümlerin planlandığı bir süreçte güncel araştırmalara ihtiyaç duyulduğu açıktır. $\mathrm{Bu}$ gerekliliğe rağmen alan yazında güncel yeterliklere ilişkin öğretmenlerin ve öğretmen adaylarının öz değerlendirmelerini konu edinen araştırmalar sınırlıdır (Çelik, Yorulmaz ve Çokçalışkan, 2019; Yenen ve Kılınç, 2018). Bu nedenle bu araştırmada öğretmenlerin ve öğretmen adaylarının Öğretmenlik Mesleği Genel Yeterliklerine ilişkin öz-değerlendirmelerinin belirlenmesi amaçlanmaktadır. Araştırmada yanitı aranan sorular ise şunlardır:

1. Öğretmenlerin mesleki yeterliklerine ilişkin görüşleri nasıldır?

2. Öğretmenlerin mesleki yeterliklerine ilişkin görüşleri cinsiyete, branşa, görev yapılan okul türüne, kıdem yılına, eğitim düzeylerine göre nasıl farklılaşmaktadır?

3. Öğretmen adaylarının mesleki yeterliklerine ilişkin görüşleri nasıldır?

4. Öğretmen adaylarının mesleki yeterliklerine ilişkin görüşleri cinsiyete, sınıf düzeylerine, öğrenim gördükleri programa göre nasıl farklılaşmaktadır?

5. Öğretmen adaylarının mesleki yeterliklerine ilişkin görüşleri ile öğretmenlerin mesleki yeterliklerine ilişkin görüşleri anlamlı bir farklılık göstermekte midir?

\section{Yöntem}

\section{Araştırma Deseni}

$\mathrm{Bu}$ araştırma betimsel bir tarama araştırması olarak desenlenmiştir. Tarama araştırmaları bir evrende var olan eğilim, tutum ya da görüşleri nicel yollarla belirlemeyi amaçlar (Creswell, 2014). Bu araştırmada da öğretmenlerin ve öğretmen adaylarının MEB tarafından belirlenen öğretmenlik mesleği genel yeterliklerine ne 
derecede sahip olduklarına dair düşüncelerinin belirlenmesi amaçlandığından tarama deseni tercih edilmiştir. Bu amaçla MEB Öğretmenlik Mesleği Genel Yeterliklerine dayalı olarak oluşturulan ölçme aracı ile öğretmen ve öğretmen adaylarından veri toplanmıştır.

\section{Katılımcılar}

$\mathrm{Bu}$ araştırmada veriler bir devlet üniversitesinin eğitim fakültesinde öğrenim gören birinci ve dördüncü sınıf ögrretmen adaylarından ve ilgili devlet üniversitesinin bulunduğu ilde farklı okul türlerinde görev yapan öğretmenlerden toplanmıştır. Katılımcıların seçiminde uygun örneklemeden yararlanılmıştır. Katılımcıların seçiminde gönüllülük esasına göre hareket edilmiştir.

Öğretmenler üzerinde yürütülen çalışmaya $64^{\prime} \ddot{u}(\% 55,2)$ kadın, 52'si $(\% 44,8)$ erkek olmak üzere toplam 116 öğretmen dâhil edilmiştir. Öğretmenlerin 99'u $(\% 85,3)$ lisans mezunu iken $17^{\prime}$ si $(\% 14,7)$ ise yüksek lisans mezunu olduğunu belirtmiştir. Öğretmenlerin branşlara göre dağılımını Tablo 1'de görülebilir.

Tablo 1

Araştırmaya Katılan Öğretmenlerin Branşa Göre Dağılımları

\begin{tabular}{lll}
\hline Branş & $\mathrm{f}$ & $\%$ \\
\hline Sinif & 28 & 24,1 \\
Okul öncesi & 15 & 12,9 \\
D.K.A.B. & 13 & 11,2 \\
Matematik & 11 & 9,5 \\
Beden eğitimi & 8 & 6,9 \\
Tarih & 7 & 6,0 \\
Sosyal bilgiler & 6 & 5,2 \\
Fen Bilgisi & 6 & 5,2 \\
Türkçe & 4 & 3,4 \\
Biyoloji & 4 & 3,4 \\
IHL meslek & 3 & 2,6 \\
Türk Dili & 3 & 2,6 \\
İngilizce & 2 & 1,7 \\
Görsel sanatlar & 2 & 1,7 \\
Rehberlik & 1 &, 9 \\
Coğrafya & 1 &, 9 \\
Bilişim & 1 &, 9 \\
Felsefe & 1 &, 9 \\
Toplam & 116 & 100,0 \\
\hline
\end{tabular}

Tablo 1'de görüldüğ̈ü üzere, en fazla sayıda (f=28, \%24,1) sinıf öğretmenliği, en az sayıda da ( $f=1, \% .9)$ rehberlik, coğrafya, bilişim teknolojileri ve felsefe branşlarından olmak üzere toplam 18 farklı branştan öğretmen araştırmaya katılmıştır. Okul türüne göre öğretmenlerin çalıştığı okulların dağılımı Tablo 2'de verilmiştir.

Katılımcı öğretmenler altı farklı okul türünde görev yapmaktadır. En çok sayıda öğretmen ( $f=41, \% 35,3)$ ilkokullarda görev yaparken en az sayıda öğretmen ise anaokulu ve imam-hatip lisesinde görev yapmaktadır ( $f=2, \% 1,7)$. Öğretmenlerin kıdem yılı değişkenine göre dağılımlarına bakıldığında ise, 12 öğretmen $(\% 10,3)$ 1-5 kıdem yılına, 28 öğretmen (\%24,1) 6-10 kıdem yılına, 20 öğretmen (\%17,2) 11-15 
kıdem y1lına, 18 öğretmen (\%15,5) 16-20 kıdem y1lına ve 38 öğretmen (\%32,8) 20 ve daha fazla kıdem yılına sahiptir.

Öğrenciler üzerinde yürütülen çalışmaya ise 220'si (\%80) kadın, 55'i (\%20) erkek olmak üzere toplam 275 eğitim fakültesi öğrencisi dâhil edilmiştir. Öğrencilerin 141'i (\%51,3) birinci sınıf öğrencisi iken 134'ü $(\% 48,7)$ ise dördüncü sınıf öğrencisidir. Öğrencilerin eğitim fakültesine başlangıç ve fakülteden ayrılma durumlarındaki değişikliği ortaya koyabilmek için birinci ve dördüncü sınıflardan veri toplanmıştır. Öğrencilerin bölümlere göre dağılımı Tablo 3’te görülebilir.

Tablo 2

Öğretmenlerin Okul Türüne Göre Dağılımları

\begin{tabular}{lll}
\hline Okul türü & $\mathrm{f}$ & $\%$ \\
\hline İlkokul & 41 & 35,3 \\
Ortaokul & 32 & 27,6 \\
Lise & 31 & 26,8 \\
Meslek Lisesi & 8 & 6,9 \\
Anaokulu & 2 & 1,7 \\
İmam-hatip ortaokulu & 2 & 1,7 \\
Toplam & 116 & 100,0 \\
\hline
\end{tabular}

Tablo 3'te görüldüğü üzere, yedi farklı bölümden öğrenci araştırmaya katılmıştır. Araştırmanın yapıldığı eğitim fakültesindeki toplam bölüm sayısı da yedidir. En çok sayıda öğrenci sınıf öğretmenliği bölümünde $(f=82, \% 29,8)$ eğitimine devam ederken en az sayıda öğrenci ise $(f=1, \% 0,4)$ fen bilgisi öğretmenliği bölümündedir.

Tablo 3

Öğrencilerin Bölümlere Göre Dağılımı

\begin{tabular}{lll}
\hline Bölüm & $\mathrm{f}$ & $\%$ \\
\hline Sını Öğretmenliği & 82 & 29,8 \\
İlk. Matematik Öğretmenliği & 80 & 29,1 \\
Türkçe Öğretmenliği & 46 & 16,7 \\
Okul Öncesi Öğretmenliği & 43 & 15,6 \\
Sosyal Bilgiler Öğgretmenliği & 21 & 7,6 \\
B.Ö.T.E. & 2 &, 7 \\
Fen Bilgisi Öğretmenliği & 1 &, 4 \\
Total & 275 & 100,0 \\
\hline
\end{tabular}

\section{Veri Toplama Arac1}

Çalışmada verilerin toplanması için MEB (2017) tarafından yayımlanan öğretmenlik mesleği genel yeterliklerinde yer alan göstergeler kullanılarak bir ölçme aracı geliştirilmiştir. İlgili yeterlikler mesleki bilgi, mesleki beceri ve tutum ve değerler alanlarındaki göstergelere ilişkin 65 maddeden oluşmaktadır. Oluşturulan aracın geçerlik ve güvenirlik çalışmaları gerçekleştirilmiş ve aşağıda sunulmuştur. Öğretmenlere ve öğrencilere uygulanan ölçekler ayrı ayrı analiz edilmiştir. Her bir ölçme aracı için madde toplam korelasyonları incelenmiş, doğrulayıcı faktör analizleri gerçekleştirilmiş ve güvenirlik hesaplamaları yapılmıştır. 
Öğretmenlere uygulanan ölçeğin madde toplam korelasyonları incelendiğinde tüm maddelerin toplam puanla pozitif ve anlamlı ilişki gösterdiği görülmektedir $(\mathrm{p}=.00)$. Korelasyon değerleri .679 ile .206 arasında değişmektedir. Öğretmen adaylarına uygulanan ölçeğin madde toplam korelasyonları incelendiğinde ise tüm maddelerin toplam puanla pozitif ve anlamlı ilişki gösterdiği görülmektedir $(p=.00)$. Korelasyon değerleri ise .766 ile .514 arasında değişmektedir.

Ölçek formları için uygulanan doğrulayıcı faktör analizi sonuçları neticesinde, uyum indekslerinden ilk olarak ki-kare ve serbestlik derecesi ele alınmış, ki-kare değeri serbestlik derecesine bölündüğgünde ortaya çıkan değerler ölçeğin ögrretmenlere uygulanan versiyonunda modelin mükemmel uyuma, eğitim fakültesi öğrencilerine uygulanan versiyonda ise iyi uyuma sahip olduğunu göstermiştir $\{[x 2$ $\left.=2882.06, \mathrm{Sd}=1960 p=.00\left(\chi_{2} / \mathrm{Sd}=1.47\right)\right]-[\chi 2=3997.62, \mathrm{Sd}=1897 p=.00(\chi 2 / \mathrm{Sd}=$ 2.11)\}. Ki-kare değerinin serbestlik derecesine bölünmesi sonucu elde edilen değer beşten küçükse yeterli, üçten küçükse iyi ve ikiden küçükse mükemmel uyum vardır denilebilir. Analiz neticesinde diğer uyum endekslerine bakıldığında da öğretmenlere uygulanan versiyon için $[\mathrm{RMSEA}=0.06, \mathrm{NFI}=0.99, \mathrm{NNFI}=1.11, \mathrm{RMR}$ $=0.03$, SRMR $=0.08$, GFI $=0.99$, AGFI $=0.99$, PGFI $=0.90$ CFI $=1.00]$ olarak bulunmuştur. Ölçeğin eğitim fakültesi öğrencilerine uygulanan versiyonu için ise değerler $[$ RMSEA $=0.06, \mathrm{NFI}=1.00, \mathrm{NNFI}=1.02, \mathrm{RMR}=0.02, \mathrm{SRMR}=0.05, \mathrm{GFI}=$ 0.99 , AGFI $=0.98$, PGFI $=0.90 \mathrm{CFI}=1.00]$ olarak bulunmuştur. RMSEA değeri 0'a yaklaştıkça mükemmel uyum olduğu şeklinde yorumlanırken, 1 değeri uyumsuzluk anlamına gelmektedir. Bu değer .05'ten küçükse iyi uyum, .06-.09 aralığından küçükse normal uyum şeklinde yorumlanmaktadır (Koçyiğit ve Karadă̆, 2016). Bu değerlere bakıldığında ölçeğin her iki uygulama için de normal düzeyde uyum gösterdiği söylenebilir.

GFI ve AGFI indeksleri 0-1 arasında değerlendirilmektedir. 0 değeri hiç uyum olmadığı, .90 iyi uyum olduğu, .95-1.0 de mükemmel uyum olduğu şeklinde yorumlanır (Jöreskog ve Sörbom, 1982; Smith ve McMillan, 2001). Buna göre her iki uygulama için de ölçeğin mükemmel uyum gösterdiği söylenebilir. CFI değeri 0-1 arasında değişir. Değerlendirme yapılırken .95-1.0 arası değerler mükemmel uyum şeklinde yorumlanır. Buna göre her iki uygulama için de ölçek mükemmel uyum göstermektedir denilebilir.

NFI ve NNFI değerleri de 0 ve 1 arasında değişir ve değer 1'e yaklaştıkça uyum mükemmelleşir (Bentler, 1990). Bu indeksler için .90 iyi uyum alt değeri olarak alınır ve .95 ya da üstü mükemmel uyuma işaret eder (Browne ve Cudeck, 1992; Hu ve Bentler, 1999; Smith ve McMillan, 2001). NNFI değerinin 1'in üzerinde çıması da olasıdır, bu gibi durumlarda değerin 1 olduğu varsayılır (Bentler, 1990). Bu kriterler dikkate alındığında her iki uygulama için de ölçeğin mükemmel düzeyde uyum gösterdiği söylenebilir.

RMR ve SRMR değerleri 0 ila 1 arasında değişir. Değerler .05 ten küçük veya eşitse mükemmel uyuma, $.08^{\prime}$ den küçük veya eşitse iyi uyuma, $.10^{\prime}$ dan küçük veya eşitse vasat uyuma işaret eder. PGFI değeri 0 olarak gerçekleşirse uyum yok, 1 olarak gerçekleşirse mükemmel uyum var şeklinde yorumlanır (Koçyiğit ve Karadağ, 2016). $\mathrm{Bu}$ kriterlere göre ölçek iyi ila mükemmel düzeylerde uyum göstermektedir denilebilir. 
Güvenirlik hesaplamaları kapsamında öğretmenlere uygulanan formun faktörler arası korelasyonları ve güvenirlik değerleri Tablo 4 'te sunulmuştur.

Tablo 4

ÖMGY Öğretmen Formu Faktörler Arası ve Toplam Puan Ortalaması Korelasyon ve Güvenirlik Değerleri

\begin{tabular}{|c|c|c|c|c|c|c|c|c|c|c|c|c|c|}
\hline & F1 & F2 & F3 & F4 & F5 & F6 & F7 & F8 & F9 & F10 & F11 & $\begin{array}{l}\text { Cronbach } \\
\text { Alpha }\end{array}$ & $\begin{array}{l}\text { Madde } \\
\text { Sayıs1 }\end{array}$ \\
\hline F1 & 1 & & & & & & & & & & & 859 & 5 \\
\hline F2 & $465^{* *}$ & 1 & & & & & & & & & & ,835 & 6 \\
\hline F3 & ,271 & $277^{* *}$ & 1 & & & & & & & & & ,837 & 5 \\
\hline F4 & ,329** &, $508^{\star *}$ & , $385^{* *}$ & 1 & & & & & & & & ,851 & 4 \\
\hline F5 & $406^{* *}$ &, $370^{* *}$ & $188^{*}$ & ,519 & 1 & & & & & & & ,878 & 7 \\
\hline F6 & ,200* & $243^{* *}$ & , $266^{* *}$ & , $424^{* *}$ &, $387^{* *}$ & 1 & & & & & & 539, & 12 \\
\hline F7 & , $345^{* *}$ & ,399** & , $275^{* *}$ & $478^{* *}$ & , $422^{* *}$ &, $421^{* *}$ & 1 & & & & & 842, & 5 \\
\hline F8 & ,287 & $242^{* *}$ &, $249^{* *}$ & $249^{* *}$ &, $367^{* *}$ & $366^{* *}$ &, $320^{* *}$ & 1 & & & & 868 & 4 \\
\hline F9 & ,219* & ,222 & $196^{*}$ &, $314^{* *}$ &, $306^{* *}$ &, $352^{* *}$ &, $381^{* *}$ & , $492^{* *}$ & 1 & & & 782, & 4 \\
\hline F10 & ,223* & ,292 & , $254^{* *}$ & $461^{* *}$ &, $297^{* *}$ &, $306^{* *}$ & $461^{* *}$ &, $555^{* *}$ & ,599 & 1 & & 881, & 6 \\
\hline F11 &, $395^{* *}$ &, $291^{* *}$ & 136 &, $400^{* *}$ & $488^{\star *}$ & $439^{* *}$ &, $416^{* *}$ &, $498^{* *}$ & $466^{* *}$ &, $606^{* *}$ & 1 & 890 & 7 \\
\hline Top &, $544^{* *}$ &, $581^{* *}$ &, $484^{* *}$ &, $704^{* *}$ &, $673^{* *}$ &, $729^{* *}$ & ,680 &, $617^{* *}$ &, $603^{* *}$ &, $676^{* *}$ &, $724^{* *}$ & .918 & 65 \\
\hline
\end{tabular}

Tablo 4 incelendiğinde tüm faktörlerin birbirleri ve ölçek geneli toplam puan ortalaması ile pozitif ve anlamlı ilişki gösterdiği görülmektedir $(p<.05)$. Ayrıca ölçeğin güvenirlik katsayısı .92 olarak bulunmuştur. Altıncı faktör hariç tüm faktörler .70 üzeri bir katsayıya sahipken, faktör altı .54 seviyesinde bir güvenirlik katsayısına sahiptir. Faktör üzerine yapılan incelemede 28. Maddenin (Alanımın eğitim ve öğretimi için gerekli olan becerileri sergileyebilirim) standart sapmasının çok yüksek olduğu ve faktörün güvenirliğini aşağı çektiği gözlemlenmiştir. Maddenin faktörden çıkarılması durumunda faktör güvenirlik katsayısının .85 düzeyine çıkacağ hesaplanmıştır. Fakat ilgili maddenin gerek madde toplam korelasyonun .30 seviyesinin üzerinde olması gerekse de ölçülmek istenen yeterlikler hususunda önemli bir madde olması gerekçesiyle ölçekten çıkarılmaması uygun görülmüştür. Sonuç olarak ölçeğin güvenilir bir ölçek olduğu söylenebilir. Öğretmen adaylarına uygulanan formun faktörler arası korelasyonları ve güvenirlik değerleri Tablo 5'te sunulmuştur.

Tablo 5 incelendiğinde tüm faktörlerin birbirleri ve ölçek geneli toplam puan ortalaması ile pozitif ve anlamlı ilişki gösterdiği görülmektedir $(p<.01)$. Ayrıca ölçeğin güvenirlik katsayısı .98 olarak bulunmuştur. Tüm faktörler .70 üzeri bir katsayıya sahiptir ve sonuç olarak ölçeğin güvenilir bir ölçek olduğu söylenebilir.

\section{Verilerin Toplanması ve Analizi}

Araştırmada veriler 2018-2019 akademik yılı bahar döneminde bir devlet üniversitesinin eğitim fakültesinde öğrenim gören birinci ve dördüncü sınıf öğrencilerinden ve aynı ilde farklı okul türlerinde görev yapan öğretmenlerden gönüllülük esasına dayalı olarak toplanmıştır. İlk olarak ilgili üniversite etik kurulundan ve ilgili ilin milli eğitim müdürlüğünden gerekli izinler alınmıştır. Çalışmada veri toplama aracı çevrimiçi bir veri toplama sistemine yüklenmiş ve 
katılımcılara veri toplama aracının linki gönderilerek kendilerine en uygun zamanda cevaplamaları istenmiştir. Ayrıca öğretmenlerden toplanan verilerin bir kısmı da öğretmenlerin basılı veri toplama araçlarına cevap vermeleri yoluyla edinilmiştir. Bu çalışmanın etik açıdan bir sakınca taşımadı̆̆ı Afyon Kocatepe Üniversitesi Sosyal ve Beşeri Bilimler Bilimsel Araştırma ve Yayın Etiği Kurulu'nun almış olduğu 11.01.2019 tarih ve 31731878-050.01.04 sayılı karar ile tespit edilmiştir. Bununla birlikte araştırmanın gerçekleştirilmesi için Afyon İl Milli Eğitim Müdürlüğü'nden izin talep edilmiş ve 04.03.2019 tarih ve 866494070605.01-E.4623615 sayılı karar ile gerekli izin verilmiştir.

Verilerin analizinde ilk olarak kullanılan ölçme aracının geçerlik ve güvenirlik çalışmaları gerçekleştirilmiştir. Madde toplam korelasyonlarının incelenmesi sonrasında yapı geçerliği için her bir form için doğrulayıcı faktör analizleri yapılmıştır. Güvenirlik için ise her bir form için faktörler arası ve toplam puan ortalaması korelasyon değerleri ve Cronbach's Alpha güvenirlik katsayısı değerleri hesaplanmıştır. Araştırma sorularına cevap vermek için ise betimsel istatistikler yapılmış ve Kolmogorov Smirnov testi aracılı̆̆ıla dağılımın normalliğine bakılmıştır. Verinin normal dağılım göstermediği görüldüğünden $(p<.05)$ nonparametrik testlerden Mann Whitney $U$ ve Kruskall Wallis gibi analiz yöntemlerinden faydalanılmıştır.

Tablo 5

ÖMGY Öğretmen Adayı Formu Faktörler Arası ve Toplam Puan Ortalaması Korelasyon ve Güvenirlik Değerleri

\begin{tabular}{|c|c|c|c|c|c|c|c|c|c|c|c|c|c|}
\hline & F1 & F2 & F3 & F4 & F5 & F6 & F7 & F8 & F9 & F10 & F11 & $\begin{array}{l}\text { Cronbach's } \\
\text { Alpha }\end{array}$ & $\begin{array}{l}\text { Madde } \\
\text { Sayis1 }\end{array}$ \\
\hline F1 & 1 & & & & & & & & & & & ,836 & 5 \\
\hline F2 & , $777^{\star *}$ & 1 & & & & & & & & & & ,856 & 6 \\
\hline F3 &, $529^{* *}$ &, $590^{* *}$ & 1 & & & & & & & & & 835 & 5 \\
\hline $\mathrm{F} 4$ &, $605^{* *}$ & ,649 &, $569^{* *}$ & 1 & & & & & & & & 855 & 4 \\
\hline F5 & $636^{* *}$ & $674^{* *}$ & $623^{* *}$ &, $735^{\star *}$ & 1 & & & & & & & 899 & 7 \\
\hline F6 & , 664 & , $684^{* *}$ & ,623 &, $722^{* *}$ &, $843^{* \star}$ & 1 & & & & & & ,919 & 12 \\
\hline F7 & ,602 & ,640 &, $543^{\star *}$ &, $665^{* *}$ & ,738 &, $789^{* *}$ & 1 & & & & & 875 & 5 \\
\hline F8 & , $500^{* *}$ &, $469^{\star *}$ &, $539^{* *}$ &, $518^{\star *}$ & ,638 & , $666^{* *}$ &, $564^{* *}$ & 1 & & & & ,922 & 4 \\
\hline F9 & $4666^{* *}$ &, $415^{\star *}$ &, $473^{\star *}$ &, $462^{* *}$ &, $576^{* *}$ & ,609 &, $570^{\star *}$ &, $773^{* *}$ & 1 & & & 855 & 4 \\
\hline F10 & ,521 & , $484^{* *}$ &, $531^{* *}$ &, $589^{* *}$ & ,674 &, $716^{* *}$ & ,623 &, $764^{* *}$ &, $747^{* *}$ & 1 & & 886 & 6 \\
\hline F11 &, $516^{* *}$ & , $478^{\star *}$ &, $532^{* *}$ &, $568^{* *}$ & , $617^{* \star}$ & , 654 &, $590^{* *}$ & ,693 & ,700 & , $771^{* *}$ & 1 & ,856 & 6 \\
\hline TOP &, $766^{* *}$ &, $781^{\star *}$ &, $739^{* *}$ &, $794^{* *}$ &, $886^{* *}$ &, $919^{* *}$ &, $830^{* *}$ &, $784^{* *}$ &, $742^{* *}$ &, $828^{* *}$ &, $791^{* *}$ & .977 & 64 \\
\hline
\end{tabular}

\section{Bulgular}

\section{Öğretmenlerin Yeterliklerine İlişkin Görüşlerine Dair Bulgular}

Öğretmenlerin mesleki yeterliklerine ilişkin görüşlerinin durumunu belirlemek için ölçek genelinden ve faktörlerden aldıkları puan ortalamaları ve standart sapmaları Tablo 6'da sunulmuştur. 
Tablo 6

Öğretmenlerin Ölçek Genelinden ve Faktörlerden Aldıkları Puan Ortalamaları ve Standart Sapmaları

\begin{tabular}{llll}
\hline Faktör & Ortalama & Ortalama Hatasi & SS \\
\hline Alan Bilgisi & 4,4312 &, 03861 &, 41584 \\
Alan Eğitimi Bilgisi & 4,3295 &, 03918 &, 42194 \\
Mevzuat Bilgisi & 4,3125 &, 04830 &, 52019 \\
Eğitim Öğretimi Planlama & 4,5033 &, 04551 &, 49012 \\
Öğrenme Ortamları Oluşturma & 4,4395 &, 03882 &, 41808 \\
Öğretme ve Öğrenme Sürecini Yönetme & 4,4474 &, 04583 &, 49359 \\
Ölçme ve Değerlendirme & 4,4397 &, 04011 &, 43196 \\
Milli, Manevi ve Evrensel Değerler & 4,6616 &, 03802 &, 40947 \\
Öğrenciye Yaklaşım & 4,4935 &, 03985 &, 44891 \\
İletişim ve İş Birliği & 4,5704 & 04168 &, 40306 \\
Kişisel ve Mesleki Gelişim & 4,5654 &, 03742 &, 29089 \\
Mesleki Yeterlik Ortalama & 4,4670 &, 02701 & \\
\hline
\end{tabular}

Tablo 6'da görüldüğ ü gibi, öğretmenler mesleki yeterlikler konusunda yüksek seviyede olduğunu düşünmektedirler. Bu aynı şekilde ölçek faktörlerinden alınan puan ortalamalarına da yansımıştır. Yeterlik boyutlarından en yüksek ortalama ve ikinci en düşük standart sapma değerlerine sahip olan faktör "Milli, manevi ve evrensel değerler" faktörü olmuştur $(x=4.66$, ss=.41). Öğretmenler bu boyutta mesleki yeterliklerini oldukça yüksek görmektedir ve grubun aldıkları puanlar da oldukça homojendir. Öğretmenlerin en düşük puan ortalaması ve en yüksek standart sapmaya sahip olduğu faktör ise "mevzuat bilgisi" faktörüdür. Buna göre öğretmenler bu boyuttaki yeterliklerini diğer boyutlardan daha düşük düzeyde görmektedir ve bu konuda almış oldukları puanlar da diğer boyutlara göre daha heterojen bir dağılım göstermektedir.

\section{Öğretmenlerin Mesleki Yeterliklerine İlişkin Görüşlerinin Değişkenlere Göre Farklılaşma Durumuna Dair Bulgular}

Cinsiyet değişkenine ilişkin bulgular. Öğretmenlerin mesleki yeterliklerine ilişkin görüşlerinin cinsiyete göre nasıl farklılaştığını tespit etmek için yapılan MannWhitney U testi sonuçları Tablo 7'de sunulmuştur.

Tablo 7

Öğretmenlerin Mesleki Yeterliklerine İlişkin Görüşlerinin Cinsiyete Göre Farklılaşma Durumlarn Mann-Whitney U Testi

\begin{tabular}{lllllll}
\hline & Cinsiyet & Ort. Sıra & Top. Sıra & z & U & $\begin{array}{l}\text { Sig. } \\
\text { yönlü) }\end{array}$ \\
\hline Mevzuat Bilgisi & Kadın & 52,03 & 3330,00 & $-2,315$ & $1250,000,021$ \\
& Erkek & 66,46 & 3456,00 & & & \\
İletişim ve İş Birliği & Kadın & 66,49 & 4255,50 & $-2,902$ & $1152,500,004$ \\
\multirow{2}{*}{ Kişisel ve Mesleki Gelişim } & Erkek & 48,66 & 2530,50 & & & \\
& Kadın & 64,43 & 4123,50 & $-2,148$ & $1284,500,032$ \\
\hline
\end{tabular}

Analiz sonucunda, öğretmenlerin ölçekten aldıkları genel puanın cinsiyete göre anlamlı bir farklılık göstermediği bulunmuştur. Diğer alt boyutlar için Tablo 8'de görüldüğü üzere "Mevzuat bilgisi", "İletişim ve işbirliği”" ve "Kişisel ve mesleki 
gelişim" faktörlerinde alınan puanların ortalamalarının cinsiyet değişkenine göre anlamlı bir farklılık gösterdiği tespit edilmiştir.

Tablo 8

Öğretmenlerin Mesleki Yeterliklerine İlişkin Görüşlerinin Cinsiyete Göre Farklllaşma Gösterdiği Boyutlarda Ortalamalar

\begin{tabular}{|c|c|c|c|c|}
\hline & Cinsiyet & Ortalama & SS & Std Hata Ort \\
\hline \multirow{2}{*}{ Mevzuat Bilgisi } & Kadın & 4,2005 & ,57317 & , 07165 \\
\hline & Erkek & 4,4505 & ,41131 & ,05704 \\
\hline \multirow{2}{*}{ İletişim ve İş Birliği } & Kadın & 4,6849 & 39632, & ,04954 \\
\hline & Erkek & 4,4295 & ,47296 & ,06559 \\
\hline \multirow{2}{*}{ Kişisel ve Mesleki Gelişim } & Kadın & 4,6334 & ,39839 & ,04980 \\
\hline & Erkek & 4,4817 & ,39663 & ,05500 \\
\hline
\end{tabular}

Farkın yönünü tespit etmek için ortalamalara bakıldı̆̆ında "mevzuat bilgisi" boyutunda kadınların ortalaması 4,20 iken erkeklerin ortalaması 4,45 olarak gerçekleşmiştir. Bu boyutta erkek öğretmenler kendilerini kadın öğretmenlere göre daha yeterli olarak görmektedir. "İletişim ve iş birliği" ve "kişisel ve mesleki gelişim" faktörlerinde ise kadın öğretmenler kendilerini erkek öğretmenlere göre daha yeterli olarak görmektedirler.

Branş değişkenine ilişkin bulgular. Öğretmenlerin puanlarında branş değişkenine göre anlamlı bir farklılaşma olup olmadığını sınamak amacıyla yapılan Kruskall Wallis analizi sonucunda, puan ortalamaları branş değişkenine göre anlamlı bir farklılık göstermemektedir ( $p>.05)$.

Görev yapılan okul türü değişkenine ilişkin bulgular. Öğretmenlerin puanlarında okul türü değişkenine göre anlamlı bir farklılaşma olup olmadığını sınamak amacıyla Kruskall Wallis testi yapılmıştır. Analiz sonucunda, puan ortalamaları okul türü değişkenine göre anlamlı bir farklılık göstermemektedir $(p>$.05).

Kıdem yılı değişkenine ilişkin bulgular. Öğretmenlerin puanlarında kıdem yılı değişkenine göre anlamlı bir farklılaşma olup olmadığını sınamak amacıyla tek yönlü varyans analizi Kruskall Wallis testi yapılmıştır (Tablo 9).

Alan bilgisi faktörü ile ilgili olarak farklılaşmanın yönünün tespiti amacıyla yapılan ikili karşılaştırmalar (Mann Whitney U testleri) neticesinde 11-15 ile 20+ yıl arasinda 11-15 lehine ( $\mathrm{p}=.016), 15-20$ ile 20+ y1l arasinda 15-20 lehine ( $p=.011), 6-10$ y1l ile 11-15 yıl arasinda 11-15 lehine $(\mathrm{p}=.048)$ ve 6-10 yil ile 15-20 yıl arasinda 15-20 yıl lehine $(p=.041)$ anlamlı farkl1lıklar tespit edilmiştir. Buna göre alan bilgisi ortalamalarında kıdem yılı düşük olanlarla çok yüksek olanlardan ziyade 11 ila 20 yıl arasında olan grupların ortalamalarının daha yüksek olduğu yorumu yapılabilir. Öğrenme ortamları oluşturma boyutunda ikili karşılaştırmalarda 20+ ile 1-5 arasında 1-5 lehine ( $p=.045)$, kişisel ve mesleki gelişim boyutunda ise 20+ ile 11-15 arasında 1115 lehine $(p=.003)$ anlamlı farklılık tespit edilmiştir. Buna göre daha düşük kıdeme sahip öğretmenler en yüksek kıdeme sahip öğretmenlere göre öğrenme ortamları oluşturmada kendilerini daha yeterli görmekte, 11-15 yıl k1deme sahip öğretmenler ise kişisel ve mesleki gelişim boyutunda $20+$ yll kıdeme sahip olan öğretmenlere göre kendilerini daha yeterli görmektedirler yorumu yapılabilir. 
Tablo 9

Kıdem Yılı Değişkenine Göre Kruskall Wallis Testi Sonuçları

\begin{tabular}{lllllll}
\hline Faktör & Kidem Y1lı & $\mathrm{N}$ & Ort. Sira & sd & Ki-Kare & $\mathrm{p}$ \\
\hline \multirow{4}{*}{ Alan Bilgisi } & $1-5$ & 12 & 54,21 & & & \\
& $6-10$ & 28 & 52,23 & 4 & & \\
& $11-15$ & 20 & 72,03 & & 10,926 &, 027 \\
& $15-20$ & 18 & 73,75 & & & \\
Öğrenme Ortamları & $20+$ & 38 & 50,13 & & & \\
Oluşturma & $1-5$ & 12 & 77,67 & & & \\
& $6-10$ & 28 & 61,20 & 4 & \multirow{2}{*}{036,302} & \\
& $11-15$ & 20 & 66,28 & & & \\
Kişisel ve Mesleki Gelişim & $15-20$ & 18 & 58,42 & & & \\
& $20+$ & 38 & 46,41 & & & \\
& $1-5$ & 12 & 51,88 & & & \\
& $6-10$ & 28 & 60,64 & 4 & & \\
& $11-15$ & 20 & 78,28 & & & \\
& $15-20$ & 18 & 65,08 & & & \\
& $20+$ & 38 & 45,49 & & & \\
\end{tabular}

Eğitim düzeyi değişkenine ilişkin bulgular. Bu sorunun cevabını tespit etmek amacıyla yapılan Mann Whitney U testi sonuçlarına göre öğretmenlerin mesleki yeterliklerinin eğitim düzeylerine göre anlamlı bir farklılık göstermediği belirlenmiştir ( $\mathrm{p}>$.05).

\section{Öğretmen Adaylarının Yeterliklerine İlişkin Görüşlerine Dair Bulgular}

Öğretmen adaylarının mesleki yeterliklerine ilişkin algılarının nasıl olduğu sorusuna yanıt almak için ölçek genelinden ve faktörlerden aldıkları puan ortalamaları ve standart sapmaları Tablo 10'da sunulmuştur.

Tablo 10

Öğretmen Adaylarının Ölçek Genelinden ve Faktörlerden Aldıkları Puan Ortalamaları ve Standart Sapmalar

\begin{tabular}{llll}
\hline Faktör & Ortalama & Ortalama Hatasi & SS \\
\hline Alan Bilgisi & 3,9753 &, 03239 &, 53706 \\
Alan Eğitimi Bilgisi & 3,8333 &, 03557 &, 58986 \\
Mevzuat Bilgisi & 3,9091 &, 03887 &, 64459 \\
Eğitim Öğretimi Planlama & 4,1873 &, 03415 &, 56625 \\
Öğrenme Ortamları Oluşturma & 4,2353 &, 03214 &, 53304 \\
Öğretme ve Öğrenme Sürecini Yönetme & 4,1527 &, 02991 &, 49599 \\
Ölçme ve Değerlendirme & 4,1418 &, 03486 &, 57803 \\
Milli, Manevi ve Evrensel Değerler & 4,4945 &, 03408 &, 56508 \\
Öğrenciye Yaklaşım & 4,4482 &, 03512 &, 58243 \\
İletişim ve İş Birliği & 4,3618 &, 03358 &, 55688 \\
Kişisel ve Mesleki Gelişim & 4,4024 &, 03112 &, 51604 \\
Mesleki Yeterlik Ortalama & 4,1831 &, 02723 &, 45149 \\
\hline
\end{tabular}

Tablo 10 incelendiğinde, öğretmen adaylarının en düşük ortalamalara ve en yüksek standart sapma değerlerine sahip oldukları faktörler "alan eğitimi bilgisi" ve "mevzuat bilgisi" faktörleridir. En yüksek ortalamaya sahip oldukları faktörler ise "milli manevi ve evrensel" değerler ile "öğrenciye yaklaşım" faktörleri olmuştur. 


\section{Öğretmen Adaylarının Mesleki Yeterliklerine İlişkin Görüşlerinin Değişkenlere} Göre Farklılaşma Durumuna Dair Bulgular

Cinsiyet değişkenine ilişkin bulgular. Yapılan Mann Whitney U testi sonuçlarına göre öğretmen adaylarının mesleki yeterliklerine ilişkin görüşleri cinsiyete göre anlamlı bir farklılık göstermemektedir ( $p>.05)$.

Sınıf düzeyi değişkenine ilişkin bulgular. Yapılan bağımsız örneklemler $t$ testi sonuçlarına göre öğretmen adaylarının mesleki yeterliklerine ilişkin görüşlerinin farklılaşma durumuna ilişkin bulgular Tablo 11'de sunulmuştur.

Tablo 11

Sınıf Düzeyi Değişkenine Göre Mann Whitney U Testi

\begin{tabular}{|c|c|c|c|c|c|c|c|}
\hline Faktör & Sinif & Ort. Sira & Top. Sira & $\mathrm{z}$ & $\mathrm{U}$ & $\begin{array}{l}\text { Sig. } \\
\text { yönlü) }\end{array}$ & (2- \\
\hline \multirow[t]{2}{*}{ Alan Bilgisi } & 1. sinif & 124,64 & 17574,0 & \multirow[b]{2}{*}{$-2,896$} & \multirow[b]{2}{*}{7563,000} & \multirow{2}{*}{\multicolumn{2}{|c|}{, 004}} \\
\hline & 4. sinif & 152,06 & 20376,0 & & & & \\
\hline \multirow[t]{2}{*}{ Alan Eğitimi Bilgisi } & 1. sinif & 120,79 & 17031,5 & \multirow{2}{*}{$-3,704$} & \multirow{2}{*}{7020,500} & \multirow{2}{*}{\multicolumn{2}{|c|}{,000 }} \\
\hline & 4. sinif & 156,11 & 20918,5 & & & & \\
\hline \multirow[t]{2}{*}{ Eğitim Öğretimi Planlama } & 1. sinif & 127,77 & 18015,5 & \multirow{2}{*}{$-2,253$} & \multirow{2}{*}{8004,500} & \multirow{2}{*}{\multicolumn{2}{|c|}{, 024}} \\
\hline & 4. sinif & 148,76 & 19934,5 & & & & \\
\hline \multirow[t]{2}{*}{ Öğrenme Ortamları Oluşturma } & 1. sinif & 126,44 & 17828,5 & \multirow{2}{*}{$-2,498$} & \multirow{2}{*}{7817,500} & \multirow{2}{*}{\multicolumn{2}{|c|}{,013 }} \\
\hline & 4. sinif & 150,16 & 20121,5 & & & & \\
\hline Öğretme ve Öğrenme Sürecini & 1. sinif & 124,34 & 17532 & \multirow{2}{*}{$-2,934$} & \multirow{2}{*}{7521,000} & \multirow{2}{*}{\multicolumn{2}{|c|}{, 003}} \\
\hline Yönetme & 4. sinif & 152,37 & 20418 & & & & \\
\hline \multirow[t]{2}{*}{ Ölçme ve Değerlendirme } & 1. sinuf & 126,01 & 17767,5 & \multirow{2}{*}{$-2,594$} & \multirow{2}{*}{7756,500} & \multirow{2}{*}{\multicolumn{2}{|c|}{,009 }} \\
\hline & 4. sinif & 150,62 & 20182,5 & & & & \\
\hline \multirow[t]{2}{*}{ Genel Yeterlik Ortalama } & 1. sinif & 125,29 & 17666 & \multirow{2}{*}{$-2,719$} & \multirow{2}{*}{7655,000} & \multirow{2}{*}{\multicolumn{2}{|c|}{, 007}} \\
\hline & 4. sinif & 151,37 & 20284 & & & & \\
\hline
\end{tabular}

Tablo 11'de belirtildiği gibi, analiz sonucunda alan bilgisi, alan eğitimi bilgisi, eğitim öğretimi planlama, öğrenme ortamları oluşturma, öğretme ve öğrenme sürecini yönetme ve ölçme değerlendirme faktörlerinde ve genel ortalamada sınıf düzeyi değişkenine göre anlamlı farklılıklar tespit edilmiştir. Bu faktörlerden alınan ortalama ve standart sapma değerleri Tablo 12' de sunulmuştur.

Tablo 12

Sınıf Düzeyi Değişkenine Göre Farklılık Gösteren Faktörlerden Alınan Puan Ortalama ve Standart Sapma Değerleri

\begin{tabular}{|c|c|c|c|c|}
\hline & Sinnf Düzeyi & Ortalama & ss & Std. Hata Ort \\
\hline \multirow{2}{*}{ Alan Bilgisi } & 1. Sinuf & 3,8950 & ,51856 & ,04367 \\
\hline & 4. Sinif & 4,0597 & ,54512 & 04709 \\
\hline \multirow{2}{*}{ Alan Eğitimi Bilgisi } & 1. Sinif & 3,7340 & ,57355 & 04830 \\
\hline & 4. Sinif & 3,9378 & ,59082 & 05104 \\
\hline \multirow{2}{*}{ Eğitim Öğretimi Planlama } & 1. Sinif & 4,1294 & ,55065 & 04637 \\
\hline & 4. Sinif & 4,2481 & ,57803 & 04993 \\
\hline Öğrenme Ortamları & 1. Sinif & 4,1783 & ,50397 & ,04244 \\
\hline Oluşturma & 4. Sinif & 4,2953 & 55762 & ,04817 \\
\hline Öğretme ve Öğrenme & 1. Sinif & 4,0987 & 44761 & ,04648 \\
\hline Sürecini Yönetme & 4. Sinif & 4,2096 & ,53810 & ,04648 \\
\hline \multirow{2}{*}{ Ölçme ve Değerlendirme } & 1. Sinif & 4,0681 & ,54816 & 04616 \\
\hline & 4. Sinif & 4,2194 & 60019 & ,05185 \\
\hline
\end{tabular}




\begin{tabular}{lllll}
\cline { 2 - 4 } Genel Yeterlik Ortalama & 1. Sinif & 4,1349 &, 41426 &, 03489 \\
& 4. Sinif & 4,2338 &, 48399 &, 04181 \\
\hline
\end{tabular}

Tablo 12'de görüldüğü üzere, altı faktörde ve genel ortalamada dördüncü sınıfta bulunan öğrenciler birinci sınıfta bulunan öğrencilere göre kendilerini daha yeterli görmektedirler; fakat daha heterojen bir dağılım ortaya koymuşlardır. Mevzuat bilgisi, milli, manevi ve evrensel değerler, öğrenciye yaklaşım, iletişim ve iş birliği, kişisel ve mesleki gelişim gibi boyutlarda ise eğitim fakültesinde okuyan bir öğretmen adayı için birinci sınıftan dördüncü sınıfa geçen süreç sonunda herhangi bir farklılaşma olmaması da dikkat çekicidir.

Öğrenim gördükleri program değişkenine ilişkin bulgular. Öğretmen adaylarının puanlarında, öğrenim gördükleri program değişkenine göre anlamlı bir farklılaşma olup olmadığını sınamak amacıyla Kruskall Wallis testi yapılmıştır. Ölçek genelinde öğrenim görülen program değişkenine göre anlamlı bir farklılık bulunamamıştır $(p>.05)$. Fark bulunan faktörlere ilişkin sonuçlar ise Tablo 13'te sunulmuştur.

Tablo 13

Öğrenim Görülen Bölüm Değişkenine Göre Kruskall Wallis Testi Sonuçlarn

\begin{tabular}{|c|c|c|c|c|c|c|}
\hline Faktör & Bölüm & $\mathrm{N}$ & Ort. Sira & $\mathrm{sd}$ & Ki-Kare & $\mathrm{p}$ \\
\hline \multirow{7}{*}{ Mevzuat Bilgisi } & İlköğrt. Matematik Öğrt. & 80 & 117,54 & \multirow{7}{*}{6} & \multirow{7}{*}{13,836} & \multirow{7}{*}{,032 } \\
\hline & Okul Öncesi Öğretmenliği & 43 & 146,79 & & & \\
\hline & Sınıf Öğretmenliği & 82 & 135,38 & & & \\
\hline & Fen Bilgisi Öğrt. & 1 & 154,50 & & & \\
\hline & Türkçe Öğretmenliği & 46 & 148,64 & & & \\
\hline & Sos. Bilg. Öğrt. & 21 & 176,76 & & & \\
\hline & BÖTE & 2 & 214,75 & & & \\
\hline \multirow{7}{*}{ Eğitim Öğretimi Planlama } & İlköğrt. Matematik Öğrt. & 80 & 113,78 & \multirow{7}{*}{6} & \multirow{7}{*}{15,658} & \multirow{7}{*}{,016 } \\
\hline & Okul Öncesi Öğretmenliği & 43 & 158,26 & & & \\
\hline & Sınıf Öğretmenliği & 82 & 143,78 & & & \\
\hline & Fen Bilgisi Öğrt. & 1 & 255,50 & & & \\
\hline & Türkçe Öğretmenliği & 46 & 144,33 & & & \\
\hline & Sos. Bilg. Öğrt. & 21 & 139,93 & & & \\
\hline & BÖTE & 2 & 210,00 & & & \\
\hline
\end{tabular}

Tablo 13'te görüldüğü üzere, sadece "mevzuat bilgisi" ve "eğitim öğretimi planlama" faktörlerinde anlamlı farklılıklar bulunmuştur $(p<.05)$. Farklılığın yönünü tespit edebilmek için yapılan ikili karşılaştırma neticesinde "eğitim öğretimi planlama" faktöründe ilköğretim matematik öğretmenliği programı ile okul öncesi öğretmenliği, arasında ilköğretim matematik öğretmenliği programı aleyhinde bir fark belirlenmiştir ( $p=.049)$. "Mevzuat bilgisi" faktöründe ise ilköğretim matematik öğretmenliği programı ile sosyal bilgiler öğretmenliği arasında ilköğretim matematik öğretmenliği aleyhinde bir fark belirlenmiştir $(p=.046)$.

\section{Öğretmen Adaylarının ve Öğretmenlerin Mesleki Yeterliklerine İlişkin Görüşleri Arasındaki Farklılığa Dair Bulgular}

Öğretmen adaylarının ve öğretmenlerin mesleki yeterliklerine ilişkin ortalamalar karşılaştırıldığında öğretmenlerin ölçek genelinden ve faktörlerinden daha yüksek 
ortalamalar aldığı görülmektedir. Bu farklılıkların anlamlılık düzeyini belirlemek için yapılan Mann Whitney U testi sonuçları Tablo 14'te sunulmuştur.

Tablo 14

Mann Whitney U Testi Sonuçlarn

\begin{tabular}{|c|c|c|c|c|c|c|}
\hline Faktör & Sinif & $\begin{array}{l}\text { Ort. } \\
\text { Sira }\end{array}$ & Top. Sira & $\mathrm{z}$ & $\mathrm{U}$ & $\begin{array}{ll}\text { Sig. } & (2- \\
\text { yönlü) }\end{array}$ \\
\hline Alan Bilgisi & $\begin{array}{l}\text { Öğg Aday } \\
\text { Öğretmen }\end{array}$ & $\begin{array}{l}166,29 \\
266,44\end{array}$ & $\begin{array}{l}45728,5 \\
30907,5\end{array}$ & $-8,112$ & 7778,5 &, 000 \\
\hline Alan Eğitimi Bilgisi & $\begin{array}{l}\text { Öğr Aday } \\
\text { Öğretmen }\end{array}$ & $\begin{array}{l}164,35 \\
271,04\end{array}$ & $\begin{array}{l}45195 \\
31441\end{array}$ & $-8,580$ & 7245 & 000 \\
\hline Mevzuat Bilgisi & $\begin{array}{l}\text { Öğg Aday } \\
\text { Öğretmen }\end{array}$ & $\begin{array}{l}173,68 \\
248,91\end{array}$ & $\begin{array}{l}47762 \\
28874\end{array}$ & $-6,051$ & 9812 & 000 \\
\hline Eğitim Öğretimi Planlama & $\begin{array}{l}\text { Öğg Aday } \\
\text { Öğretmen }\end{array}$ & $\begin{array}{l}176,48 \\
242,28\end{array}$ & $\begin{array}{l}48532 \\
28104\end{array}$ & $-5,378$ & 10582 & 000 \\
\hline Öğrenme Ortamları Oluşturma & $\begin{array}{l}\text { Öğr Aday } \\
\text { Öğretmen }\end{array}$ & $\begin{array}{l}182,52 \\
227,96\end{array}$ & $\begin{array}{l}50193 \\
26443\end{array}$ & $-3,669$ & 12243 & 000 \\
\hline $\begin{array}{l}\text { Ögrretme ve Öğrenme Sürecini } \\
\text { Yönetme }\end{array}$ & $\begin{array}{l}\text { Öğr Aday } \\
\text { Öğretmen }\end{array}$ & $\begin{array}{l}175,35 \\
244,97\end{array}$ & $\begin{array}{l}48220 \\
28416\end{array}$ & $-5,582$ & 10270 & 000 \\
\hline Ölçme ve Değerlendirme & $\begin{array}{l}\text { Öğr Aday } \\
\text { Öğretmen }\end{array}$ & $\begin{array}{l}177,49 \\
239,89\end{array}$ & $\begin{array}{l}48809 \\
27827\end{array}$ & $-5,049$ & 10859 &, 000 \\
\hline $\begin{array}{l}\text { Milli, Manevi ve Evrensel } \\
\text { Değerler }\end{array}$ & $\begin{array}{l}\text { Öğr Aday } \\
\text { Öğretmen }\end{array}$ & & $\begin{array}{l}51530 \\
25106\end{array}$ & $-2,455$ & 13580 & 014 \\
\hline Öğrenciye Yaklaşım & $\begin{array}{l}\text { Öğr Aday } \\
\text { Öğretmen }\end{array}$ & $\begin{array}{l}195,91 \\
196,21\end{array}$ & $\begin{array}{l}53875,5 \\
22760,5\end{array}$ &,- 025 & 15925,5 & ,980 \\
\hline İletişim ve İş Birliği & $\begin{array}{l}\text { Öğr Aday } \\
\text { Öğretmen }\end{array}$ & $\begin{array}{l}182,45 \\
228,13\end{array}$ & $\begin{array}{l}50173,5 \\
26462,5\end{array}$ & $-3,690$ & 12223,5 & ,000 \\
\hline Kişisel ve Mesleki Gelişim & $\begin{array}{l}\text { Öğr Aday } \\
\text { Öğretmen }\end{array}$ & $\begin{array}{l}184,43 \\
223,42\end{array}$ & $\begin{array}{l}50719 \\
25917\end{array}$ & $-3,146$ & 12769 & 002 \\
\hline Genel Yeterlik Ortalama & $\begin{array}{l}\text { Öğr Aday } \\
\text { Öğretmen }\end{array}$ & $\begin{array}{l}171,86 \\
253,23\end{array}$ & $\begin{array}{l}47261,5 \\
29374,5\end{array}$ & $-6,503$ & 9311,5 & ,000 \\
\hline
\end{tabular}

Öğretmenlerle öğretmen adaylarının aldıkları puanların ortalamaları karşılaştırıldığında "öğrenciye yaklaşım hariç" tüm alt boyutlarda ve ölçek genelinde öğretmenler lehine anlamlı farklılaşma tespit edilmiştir. Buna göre öğrenciler mesleğe başlamadan henüz kendilerini tam olarak yeterli görmeme eğilimindedir. Öğrenciye yaklaşım boyutunda ise kendilerinin öğrenci olmasından hareketle daha yüksek puan ortalamalarına sahip olmaları ihtimali değerlendirilebilir.

\section{Tartışma, Sonuç ve Öneriler}

$\mathrm{Bu}$ araştırmanın amacl, “Öğretmenlik Mesleği Genel Yeterlikleri” belgesinde belirtilen yeterlik alanları uyarınca öğretmen ve öğretmen adaylarının kendilerini nasıl değerlendirdiklerini belirlemektir. Araştırmanın bulgularına göre öğretmenler mesleğe ilişkin yeterliklerini yüksek düzeyde algılamaktadır. Yeterlik alanlarına bakıldığında öğretmenlerin kendilerini en olumlu olarak "tutum ve değerler" alanında değerlendirdikleri ve bunu "mesleki beceri" alanının takip ettiği belirlenmiştir. Öğretmenler "mesleki bilgi" alanındaki yeterliklerini ise diğer iki alana göre daha düşük algılamaktadır.

Öğretmen adayları ise yeterliklerini öğretmenlerden daha düşük düzeyde algılamaktadır. Öğretmen adayları da kendilerini en yüksek düzeyde "tutum ve değerler" alanında yeterli olarak görmüşlerdir. Bunu "mesleki beceri" ve "mesleki bilgi" yeterlik alanları takip etmektedir. Buna paralel olarak Yenen ve Kılınç (2018) 
öğretmenlerin mesleki bilgi, mesleki beceri ve tutum ve değerler boyutlarında kendilerini yeterli gördüklerini tespit etmiştir. Göçmen (2014), Kararmaz ve Arslan (2012), Taşar (2012), Eraslan Keskinkılıç (2010) ve Karacaoğlu (2008) da öğretmenlerin mesleki yeterlik algılarının olumlu olduğu bulgusuna ulaşmışlardır. Bununla birlikte, Çayak (2014) ilkokul öğretmenlerinin yapılandırmacı yaklaşımı uygulama konusunda kendilerini yeterli gördüğünü belirlemiştir.

Gerçekleştirilen çalışmalarda, İyison ve Onur Sezer (2017) ile Kahramanoğlu ve Ay (2013) sınıf öğretmeni adayları, Dilci ve Yıldız (2012) Türkçe, sınıf ve sosyal bilgiler öğretmen adayları, Coşkun, Özer ve Tiryaki (2010) Türkçe öğretmen adayları, Yeşilyurt (2011) tezsiz yüksek lisans eğitimi almakta olan öğretmen adayları ve Özer ve Gelen (2008) farklı bölümlerde okuyan öğretmen adaylarının yeterlik algılarının yüksek düzeyde olduğunu belirlemiştir. Çelik, Yorulmaz ve Çokçalışkan (2019) yaptıkları çalışmada sınıf öğretmenleri ve adayların öğretmenlik mesleği genel yeterlikleri açısından kendilerini yüksek düzeyde bir ortalama ile değerlendirdiklerini tespit etmiştir.

Hem öğretmenler hem de adaylar "tutum ve değerler" alanında en yüksek yeterlik düzeyine sahip olduklarını düşünmektedir. Hem öğretmenler hem de adaylar, yeterliklerin "duyuşsal” yönünü içeren bu alana dair kendilerini yüksek düzeyde yeterli görmektedirler. Bunun yanı sıra mesleki beceri düzeylerinin yani öğretim için ortam düzenlenmesi ve öğrencileri hedefe ulaştıracak eğitim durumlarının seçilip işe koşulması boyutunda kendilerini daha az yeterli görmektedirler. Her iki grup için en az yeterlik düzeyine ise, "mesleki bilgi" alanında rastlanmaktadır. Buna paralel olarak, Numanoğlu ve Bayır (2009) da bilgisayar öğretmen adayları üzerine yaptığı çalışmada "Kişisel ve Mesleki Değerler-Mesleki Gelişim" ana yeterliğinde "Ulusal ve Evrensel Değerlere Önem Verme" alt yeterliğine ilişkin genel ortalamayı en yüksek olarak belirlemiştir.

Öğretmen yetiştirme programları incelendiğinde Türkiye'de 1980'li yıllardan itibaren, öğretmen eğitimi programları "alan dersleri" "meslek bilgisi dersleri" "genel kültür dersleri", ve "okul deneyimi" uygulamalarından oluşmaktadır (Demirel, 1999; Senemoğlu, 2011). "Mesleki bilgi" boyutunun içerdiği kazanımlar, adaylara alan bilgisine ve özel öğretim yöntemlerine ilişkin teorik dersler ve birtakım pedagojik formasyon dersleri ile kazandırılmaya çalışılmaktadır. Öğretmen yetiştirme programındaki dersler tür değişkenine göre sınıflandırıldığında, en büyük ağırlığa sahip alan \%46-49'luk oran ile alan eğitimine dair derslerdir. Bunu \%3335'lik oran ile meslek bilgisi dersleri takip etmektedir (YÖK, 2018). Bu bağlamda, bu iki ders grubunun programdaki ağırlığı göz önüne alındığında, öğretmen ve öğretmen adaylarının "mesleki bilgi" boyutunu en az yeterliğe sahip alan olarak tanımlamaları, meslek öncesi öğretmen eğitimi ve hizmet içi eğitim olgularının etkililiğine ve çıktılarına ilişkin bir eksikliğe atfedilebilir.

Ergünay (2018) yaptığı araştırmada çalışma grubunu oluşturan üç öğretmenin de alan bilgisinde eksiklik hissettiğini, bir öğretmenin alan öğretimi bilgisinde bir öğretmenin de sınıf yönetiminde eksiklik hissettiğini belirlemiştir. Eret'e (2013) göre ise öğretmen adayları aldıkları eğitimin, kendilerini öğretimi bireysel farklılıkları göz önünde bulundurarak planlama konusunda yeteri kadar geliştirmediğini belirtmektedir. Alanyazında da hizmet öncesi ve hizmet içi eğitimin istenen nitelikte sonuçlar vermediği bulgusuna ulaşan çalışmalar mevcuttur (Ayvacı, Bakırcı ve 
Yıldız, 2014; Goff-Kfouri, 2013; Göksoy, 2014; Karasolak, Tanrıseven ve Konokman, 2013).

Bununla birlikte hizmet öncesi öğretmen eğitiminde çok az yer tuttuğu ve verimli olmadığı noktasında tespitler ve eleştiriler getirilen (Aksoy, 2013; Büyükgöze-Kavas ve Bugay 2009; Gülmez-Dağ, 2012; Kozikoğlu, 2016; Özdemir, Ceylan ve Canoğlu, 2015) uygulama boyutunu yansıtan "mesleki beceri" yeterlik alanının özellikle öğretmen adaylarında daha yüksek bulunması programın çıktıları açısından sorgulanması gereken bir durumdur. Yani çok fazla zaman ayrıldığı görülen öğretmenlik mesleği teorik eğitiminin, bu alana göre çok kısıtlı bir süreçte gerçekleştirilen öğretmenlik uygulamasından daha az yeterlik algısı oluşturması önemli bir bulgu olarak değerlendirilebilir.

Her iki grup için de en yüksek yeterlik alanı olarak tarif edilen "tutum ve değerler" alanını oluşturan yeterlikler ise genellikle duyuşsal boyutu vurgulayan yeterliklerdir. Hem öğretmenler hem de adayların en yüksek yeterliğe sahip olduklarını belirttiği "milli ve manevi değerler" yeterliği ve buna ek olarak "öğrenciye yaklaşım", "iletişim ve iş birliği" ile "kişisel ve mesleki gelişim" yeterliklerini içeren bu boyuta ilişkin kazanım ifadeleri genellikle öğretmen ve adayların eğitsel inanç ve felsefelerine ilişkindir. Bu ifadelerin sınıfta gerçekleşen öğrenme-öğretme uygulamalar yerine bunların arkasında yatan inanç ve tutumlarla yani teoriyle ilişkili olduğu görülmektedir. Bu alandaki kazanımlar direkt olarak eylemlerle ilgili yeterlikler olmaktan çok bu eylemleri etkileyen içsel dinamikler olarak değerlendirilebilir. Örneğin "Çocuk ve insan haklarını gözetir", "Bireysel ve kültürel farklılıklara saygılıdır", "Her öğrenciye insan ve birey olarak değer verir", "Her öğrencinin öğrenebileceğini savunur", "İnsan ilişkilerinde empati ve hoşgörüyü esas alır", "Meslektaşlarıyla bilgi ve deneyim paylaşımına açıktır" gibi kazanımlar daha çok eğitimsel inancın muhtevasına giren ifadeler olarak karşımıza çıkmaktadır. Bu nedenle bu alana ilişkin yeterlikler, diğer iki yeterlik alanında olduğu gibi "bilme" ve "yapma" şeklinde ifade edilmeye daha uzaktır.

$\mathrm{Bu}$ nedenle öğretmenler ve adaylar "tutum ve değerler" alanına dair yeterliklerini belirlerken, performanslarını belirleyebilecekleri net kriterlerden ziyade birtakım eğitsel olgu ve durumlara dönük inanç ve algılarını paylaşmışlardır. Buna paralel olarak öğretmen adaylarının öğretmenlik mesleğini gerçekleştirebilmek için en önemli özelliklerin sorumluluk, insan yetiştirme, sabır gerektirme, kutsal olma, yeniliklere açık olma gibi duyuşsal özellikler olduğunu ifade ettikleri çalışmalara alanyazında rastlanmaktadır (İlter, 2009; Keskin, 2013; Özbek, Kahyaoğlu ve Özgen, 2007). Dolayısıyla öğretmen ve öğretmen adayları "tutum ve değerler" bağlamında daha yüksek yeterliğe sahip olduklarını düşünürken, öğretmenlik mesleğine ilişkin kritik bilgilere sahip olma ve bunları eğitim-öğretim ortamlarına aktarma hususunda kendi yeterliklerini daha düşük algılamışlardır.

Çalışmanın bir diğer sonucuna göre ise öğretmenlerle öğretmen adaylarının aldıkları puanların ortalamaları karşılaştırıldığında "öğrenciye yaklaşım hariç" tüm alt boyutlarda ve ölçek genelinde öğretmenler lehine anlamlı farklılaşma tespit edilmiştir. Bu durum öğretmenlik mesleğinin deneyimlerle gelişen bir meslek olmasıyla ilgili olabilir. Hem meslek öncesi öğretmen eğitiminin adayları mesleğe yeteri kadar hazırlamamasına dönük bulgular hem de öğretmenlik mesleğinin öğrenci grubuna ve öğrenmenin gerçekleştiği ortam ve şartlara yakından bağlı 
olması ve gerçek ortamlarla karşılaşılmadan tam olarak özümsenmeyecek bir yap1 göstermesi bu durumu doğurmuş olabilir (Yenen ve Kılınç, 2018).

"Mesleki bilgi" alanına bakıldığında öğretmen adayları alan, alan öğretimi ve mevzuatla ilgili, aldıkları dersler aracıyla birçok bilgi edinmekte ancak bunların görev yaparken kendileri için ne düzeyde gerekli veya kullanılabilir olduğuna dair yeterli farkındalığa ancak öğretmen olduktan sonra erişebilmektedir. "Mesleki beceri" boyutu ise yeterlik belgesinin tümleci konumundadır yani öğretmenliğin "nasıl" boyutu ile ilgilidir. Bu nedenle öğretmen adayları henüz yeteri kadar öğretim deneyimi geçirmediğinden öğretmenlerden daha az yeterli olduklarını düşünmektedirler. Tutum ve değerler boyutunda da öğretmenlerin eğitim inançlarının daha yerleşik bir yapı göstermesi bu sonucu doğurmuş olabilir. Bu bağlamda Çelik, Yorulmaz ve Çokçalışkan (2019) "mesleki bilgi" alanında öğretmenlerin öğretmen adaylarına göre kendilerini daha yeterli olarak algıladığını belirlemiştir. Keskin (2013) çalışmasında öğretmen adaylarının yarısına yakının kendilerini öğretmenliğe hazır hissetmediklerini ve gerekli yeterliğe ulaşamadıkları algısında olduklarını belirtmiştir.

Öğretmenlerle öğretmen adaylarının arasında "öğrenciye yaklaşım" boyutunda anlamlı bir farklılık bulunmamıştır. Bunun nedeninin öğretmen adaylarının halen öğrenci olmaları nedeniyle, öğrenciye yaklaşım yeterliği konusunda empati kurabilecek bir durumda olmaları gösterilebilir.

Araştırmada ayrıca öğretmen ve öğretmen adaylarının yeterliklerinin birtakım değişkenlere göre anlamlı olarak farklılaşıp farklılaşmadığı incelenmiştir. Buna göre "mevzuat bilgisi" yeterliğinde erkek öğretmenlerin, "iletişim ve işbirliği" ile "kişisel ve mesleki gelişim" yeterliklerinde kadın öğretmenlerin lehine anlamlı bir farklılık belirlenmiştir. Öğretmen adaylarının yeterlikleri ise cinsiyete göre anlamlı bir farklılık göstermemiştir. Keskin (2013), Coşkun, Özer ve Tiryaki (2010) ve Coşkun, Gelen ve Öztürk (2009) de öğretmen adaylarının mesleki yeterlik ve gelişimleri üzerinde cinsiyet değişkeninin anlamlı bir farklılık oluşturmadığını belirlemiştir.

Yenen ve Kılınç (2018) yaptıkları çalışmada kişisel ve mesleki gelişim alt boyutunda kadın öğretmenler lehine anlamlı bir farklılık belirlemiştir. Alanyazındaki birtakım çalışmalar eğitim kurumları içerisinde kadın öğretmenlerin iletişim, işbirliği ve gelişmeyi sürekli hale getirmede daha becerili olduklarını göstermektedir (Aktağ ve Walter, 2005; Çapri ve Çelikkaleli, 2008; Ekici, 2006). Kararmaz ve Arslan (2014) da yaptığı çalışmada cinsiyet değişkenine göre Dil Becerilerini Geliştirme ve Okul, Aile ve Toplumla İşbirliği Yapma yeterlik alanlarında kadın öğretmenler lehine anlamlı bir farklılık bulmuştur. Bunun yanında eğitim kurumlarında yönetici olmak konusunda genellikle daha istekli olan erkek öğretmenlerin mevzuata hâkim olmayı önemli gördükleri ifade edilebilir.

Öğretmenlerin yeterlikleri branş ve görev yapılan okul türü değişkenine göre anlamlı olarak farklılaşmamaktadır. Sıra ortalamaları incelendiğinde "alan eğitimi bilgisi" yeterliğinde imam hatip lisesi öğretmenlerinin, "iletişim ve işbirliği" yeterliğinde ise ilkokul ve ortaokulda görev yapan öğretmenlere göre meslek lisesi öğretmenlerinin düşük bir algıya sahip olduğu belirlenmiştir. Bu durum özellikle meslek dersleri öğretmenlerini yetiştiren fakültelerin verdiği alan eğitim derslerinin niteliği ile ilgili olabilir. Yenen ve Kılınç (2018), Yıldırım ve Koca (2015) ve Kararmaz ve Arslan (2014) birtakım alt boyutlara ilişkin yeterliliğin eğitim fakültesi mezunu 
olan öğretmenler lehine daha olumlu olduğunu belirlemiştir. Meslek lisesinde de hem kültür hem de meslek dersleri öğretmenlerinin aynı çatı altında görev yapması ve alanları itibariyle çok farklı öğretim süreçlerini takip etmeleri, iletişim ve işbirliği noktasındaki farkı açıklamada önemli bir noktadır. Bununla birlikte yine meslek liselerinin mevcut öğrenci profili ve bu kurumlardaki öğretmenlerin algıları düşünüldüğünde bu fark ortaya çıkmış olabilir.

Kıdem yılı değişkenine göre öğrenme ortamları oluşturma yeterliğinde daha düşük kıdeme sahip öğretmenler en yüksek kıdeme sahip öğretmenlere göre kendilerini daha yeterli görmekte, 11-15 yıl kıdeme sahip öğretmenler ise kişisel ve mesleki gelişim boyutunda 20+ y1l k1deme sahip olan öğretmenlere göre kendilerini daha yeterli görmektedir. Alan bilgisi ortalamalarında ise kıdem yılı düşük olanlarla çok yüksek olanlardan ziyade 11 ila 20 yıl arasında olan grupların ortalamalarının daha yüksek olduğu yorumu yapılabilir. Bu durum özellikle mesleki deneyimin, öğretimin etkili bir şekilde düzenlenmesi noktasında etkili bir faktör olduğunu ortaya koymaktadır. Mesleğe yeni başlayan öğretmenler, gerçek sınıf ortamı ile ilk karşılaşmalarında birtakım problemler yaşamakta ve bir müddet bu problemlerin çözümüne dönük kişisel stratejiler geliştirmeye çalışmaktadırlar. Bir süre sonra deneyimin etkisi ile artık kişisel bir strateji yelpazesi edinmekte ve öğrenme ortamlarını istendik davranışları ortaya çıkarma noktasında daha yeterli bir hale gelmektedirler. Bununla birlikte, kişisel ve mesleki gelişim boyutunda yeni ve kıdemi yüksek öğretmenlerin daha olumsuz bir yeterlik algısı çizmesine rağmen, 1115 yıl kıdeme sahip öğretmenler olumlu bir yeterlik algısı ortaya koymuşlardır. Yeni göreve başlayan öğretmenler hem eksiklerinin farkına varma sürecinin başında olmaları ve hem de gündemlerinin daha çok mesleğe uyum sağlama ile ilgili olması nedeniyle kişisel ve mesleki gelişime yeteri kadar eğilememektedir. Kıdemli öğretmenlerin ise hem gelişime ihtiyacı olmadığını düşünmeleri hem de yeniliklere adapte olma hususunda problem yaşamaları bu durumu doğurmuş olabilir. Yenen ve Kılınç (2018) de öğrenme ortamları oluşturma ve ölçme ve değerlendirme alt boyutlarında 6-10 yıl kıdeme sahip öğretmenler aleyhine bulgulara ulaşmışlardır.

Öğretmen adaylarının alan bilgisi, alan bilgisi, alan eğitimi bilgisi, eğitim öğretimi planlama, öğrenme ortamları oluşturma, öğretme ve öğrenme sürecini yönetme ve ölçme değerlendirme yeterliklerinde 4 . sınıfta okuyanlar 1 . sinıfta okuyanlara göre daha olumlu bir algıya sahiptir. Bu durum öğretmen yetiştirme programları için olumlu bir durumdur. Çünkü öğrenciler eğitim fakültesinde üst sinıflara doğru ilerledikçe öğretmenlikle ilgili temel bilgiler, alanla ilgili temel kavramlar ve öğretim için önemli bir unsur olan ölçme ve değerlendirme yeterliği açısından kendilerini daha olumlu değerlendirmektedir. Ancak yeterlik belgesindeki 11 adet yeterlikten altısının bu süreçte gelişim göstermesi ise programların niteliği için bir soru işareti taşımaktadır. Bu nedenle bu altı alandaki yeterlikte meydana gelen olumlu değişim, öğretmen yetiştirme programının doğal seyri olarak da değerlendirilebilir.

Bunun yanı sıra "eğitim öğretimi planlama" faktöründe ilköğretim matematik öğretmenliği programı ile okul öncesi öğretmenliği arasında ilköğretim matematik öğretmenliği programı aleyhinde bir fark belirlenmiştir. "Mevzuat bilgisi" faktöründe ise ilköğretim matematik öğretmenliği programı ile sosyal bilgiler öğretmenliği programı arasında ilköğretim matematik öğretmenliği aleyhinde bir 
fark belirlenmiştir. Yenen ve Kılınç (2018) ise sosyal bilgiler öğretmenlerinin mevzuat bilgisine dair yeterlik algılarının daha yüksek olduğunu belirlemiştir.

Öğretmenlerin ve öğretmen adaylarının "Öğretmenlik Mesleği Genel Yeterlikleri" ne ilişkin algılarının konu edindiği bu çalışmada konuya ilişkin önemli bulgular ortaya konulmuştur. Söz konusu yeterliklerin öğretmen eğitimi ve öğretmenlik sürecinde önemli bir değişken olduğu düşünüldüğünde bu konuda güncel yeterlikler ile yapılmış daha fazla çalışmaya ihtiyaç olduğu açıktır. Bu çalışmanın sınırlıkları arasında çalışmanın sadece nicel bir yapıda olması ifade edilebilir. Bu konuda daha büyük örneklemlerle nicel çalışmalar yapılarak sonuçların karşılaştırılacağı gibi nitel verilerle desteklenen çalışmalara da ihtiyaç bulunmaktadır. Ayrıca Türkiye'nin farklı bölgelerinden verilerin toplanması da karşılaştırmaları daha anlamlı hale getirecektir. Öğretmen yeterliklerine ilişkin olarak yöneticilerin, öğrencilerin ve velilerin de görüşlerine başvurulması uygun olacaktır.

\section{Kaynakça}

Aksoy, E. (2013). A.B.D (New York), Finlandiya, Singapur ve Türkiye'de öğretmen eğitimindeki dönüşümler (2000-2010). (Yayımlanmamış doktora tezi). Ankara Üniversitesi, Ankara.

Aktă̆, I. ve Walter J. (2005). Öğretmen adaylarının mesleki yeterlilik duygusu. Spormetre Beden Eğitimi ve Spor Bilimleri Dergisi, 3(4), 127-131. https://doi.org/10.1501/Sporm_0000000055

Ayvacı, H. S., Bakırcı, H. ve Yıldız, M. (2014). Fen bilimleri öğretmenlerinin hizmet içi eğitim uygulamalarına ilişkin görüşleri ve beklentileri. Amasya Üniversitesi Eğitim Fakültesi Dergisi, 3(2), 357-383.

Bentler, P. M. (1990). Comparative fit indexes in structural models. Psychological Bulletin, 107(2), 238-246. https:/ / doi.org/10.1037/0033-2909.107.2.238

Browne, M. W., and Cudeck, R. (1992). Alternative ways of assessing model fit. Sociological Methods and Research, 21(2), 230-258. https://doi.org/10.1177/0049124192021002005

Bulut, İ. (2014). Öğretmenlerin öğrenme ve öğretme sürecine ilişkin yeterlik algıları. İlköğretim Online, 13(2), 577-593.

Büyükgöze Kavas, A. ve Bugay, A. (2009). Öğretmen adaylarının hizmet öncesi eğitimlerinde gördükleri eksiklikler ve çözüm önerileri. Pamukkale Üniversitesi Ĕ̈itim Fakültesi Dergisi, 25(1), 13-21.

Coşkun, E., Özer, B. ve Tiryaki, E.N. (2010). Türkçe öğretmeni adaylarının özel alan yeterlik algılarının değerlendirilmesi. Dokuz Eylül Üniversitesi Buca Ĕ̆itim Fakültesi Dergisi, 27, 123-136.

Coşkun, E., Gelen, İ. ve Öztürk, E. P. (2009). Türkçe öğretmeni adaylarının öğretimi planlama, uygulama ve değerlendirme yeterlik algıları. Mustafa Kemal Üniversitesi Sosyal Bilimler Enstitüsü Dergisi, 6(12), 140-163.

Creswell, J. W. (2014). Research design: qualitative, quantitative and mixed methods approaches. Los Angeles: Sage Publications.

Çapri, B. ve Çelikkaleli, Ö. (2008). Öğretmen adaylarının öğretmenliğe ilişkin tutum ve mesleki yeterlik inançlarının cinsiyet, program ve fakültelerine göre incelenmesi. İnönü Üniversitesi Ĕ̆itim Fakültesi Dergisi, 9(15), 33-53. 
Çayak, S. (2014). İlkokul öğretmenlerinin yapılandırmacı yaklaşımı uygulamaya yönelik tutumları ile özyeterlikleri arasındaki ilişki. Mehmet Akif Ersoy Üniversitesi Ĕ̆itim Fakültesi Dergisi, 31,88-110.

Çelik, Ö., Yorulmaz, A. ve Çokçalışkan, H. (2019). Öğretmen genel yeterlikleri açısından sınıf öğretmenleri ve öğretmen adaylarının kendilerini değerlendirmeleri. Eskişehir Osmangazi Üniversitesi Sosyal Bilimler Dergisi, 20 (Özel Sayı), 203-215. https://doi.org/10.17494/ogusbd.548342

Çubukcu, F. (2010). Student teachers' perceptions of teacher competence and their att-ributions for success and failure in learning. The Journal of International Social Research, 3(10), 213-217.

Dilci, T. ve Yıldız, H. (2012). Öğretmen adaylarının mesleki yeterliklerine ilişkin inançları. Sosyal Bilimler Araştırmaları Dergisi, 1, 245-265. https://doi.org/10.19129/sbad.225

Ekici, G. (2006). Meslek lisesi öğretmenlerinin öğretmen öz-yeterlik inançları üzerine bir araştırma, Ĕ̆itim Araştırmaları Dergisi, 6(24), 87-96.

Eraslan Keskinkılıç, F. (2010). İlköğretim bilişim teknolojileri öğretmenlerinin yeterliklerinin okul müdürlerinin görüşlerine göre değerlendirilmesi. Uluslararası Öğretmen Yetiştirme Politikaları ve Sorunlan Sempozyumu II, 16-18 May1s, Hacettepe Üniversitesi, Beytepe-Ankara, 116-125.

Eret, E. (2013). An assessment of pre-service teacher education in terms of preparing teacher candidates for teaching. (Yayımlanmamış doktora tezi). Orta Doğu Teknik Üniversitesi, Ankara.

Ergünay, O. (2018). Aday öğretmenlerin ilk yıl mesleki deneyimlerinin Hammerness, Darling-Hammond ve Bransford'un öğretmen eğitimi modeli bağlamında incelenmesi: Bir çoklu durum çalışması. (Yayımlanmamış doktora tezi). Anadolu Üniversitesi, Eskişehir.

Erişti, B. (2008). Öğretmenlik mesleği ve özellikleri. Işıl K. (Ed.) Öğretmenlike mesleki gelişim içinde (ss. 1-26). Eskişehir: Anadolu Üniversitesi Yayınları.

Goff-Kfouri, C. A. (2013). Pre-service teachers and teacher education. Procedia- Social and Behavioral Sciences, 93, 1786-1790. https://doi.org/10.1016/j.sbspro.2013.10.117

Göçmen, E. (2014). İnönü üniversitesi eğitim fakültesi mezunlarının mesleki yeterlik düzeyi. (Yayımlanmamış yüksek lisans tezi). İnönü Üniversitesi Eğitim Bilimleri Enstitüsü, Eğitim Bilimleri Ana Bilim Dalı, Eğitim Yönetimi ve Denetimi Bilim Dali, Malatya.

Göksoy, S. (2014). Hizmet-İçi eğitim faaliyetlerinin süreç ve sonuçlarının niteliğine yönelik öğretmen görüşleri. International Journal of Human Sciences, 11(1), 387402. https://doi.org/10.14687/ijhs.v11i1.2645

Gülmez-Dağ, G. (2012). An assessment of pre-service teacher education in terms of preparing teacher candidates for teaching. (Yayımlanmamıs yüksek lisans tezi). Orta Doğu Teknik Üniversitesi, Ankara.

Günçer, B. (1999). Türkiye'de öğretmen eğitiminde standartlar ve akreditasyon. https://www.yok.gov.tr/Documents/Yayinlar/Yayinlarimiz/turkiyede_ogre tmen_egitiminde_standartlar_ve_akreditasyon.pdf adresinden 04.10.2019 tarihinde edinilmiştir. 
Hu, L., and Bentler, P. M. (1999). Cutoff criteria for fit indexes in covariance structure analysis: Conventional criteria versus new alternatives. Structural Equation Modeling: A Multidisciplinary Journal, 6(1), 1-55. http:/ / dx.doi.org/10.1080/10705519909540118.

İlter, İ. (2009). Öğretmen adaylarının öğretmenlik mesleğine ilişkin tutumlarını bazı değişkenler açısından incelenmesi (Yayımlanmamış Yüksek Lisans Tezi), Sosyal Bilimler Enstitüsü, Elazı̆̆.

İyison, G. ve Onur-Sezer, G. (2017). Sınıf öğretmeni adaylarının öğretmenlik mesleğine yönelik tutumları ile ilkokul öğretmenlerinin yeterlilikleri arasındaki ilişkinin incelenmesi. Akademik Sosyal Araştırmalar Dergisi, 50, 528542. https://doi.org/10.16992/ ASOS.12588

Jöreskog, K. G., and Sörbom, D. (1982). Recent developments in structural equation modeling. Journal of Marketing Research, 19, 404-416. https://doi.org/10.1177/002224378201900402

Kahramanoğlu, R. ve Ay, R. (2013). Sınıf öğretmeni adaylarının özel alan yeterlik algılarının çeşitli değişkenler açısından analizi. Uluslararası Türkçe Edebiyat Kültür Dergisi, 2(2), 285-301.

Karacaoğlu, Ö. C. (2008). Öğretmenlerin yeterlik algıları. Yüzüncü Yıl Üniversitesi, Eğitim Fakültesi Dergisi, 5(1), 70-9.

Kararmaz, S. ve Arslan, A. (2014). İlköğretim İngilizce öğretmenlerinin öğretmenlik mesleği özel alan yeterliklerine ilişkin algılarının belirlenmesi. Uşak Üniversitesi Sosyal Bilimler Dergisi, 7(4), 203-232. https://doi.org/10.12780/UUSBD379

Karasolak, K., Tanrıseven, I. ve Yavuz Konokman, G. (2013). Öğretmenlerin hizmetiçi eğitim etkinliklerine ilişkin tutumlarının belirlenmesi. Kastamonu Eğitim Dergisi, 21(3), 997-1010.

Keskin, Y. (2013). Mesleki yeterliklerin kazanılma sürecinde öğretmen adaylarının görüşlerinin değerlendirilmesi. Turkish Studies, 8(3), 319-339.

Koçyiğit M., Karadağ E. (2016). Developing an ethical tendencies scale based on the theories of ethics. Turkish Journal of Business Ethics, 9(2), 283-307. https://doi.org/10.12711/tjbe.2016.9.0016

Kozikoğlu, İ. (2016). Öğretimin ilk yılı: Mesleğin ilk yılındaki öğretmenlerin karşılaştıkları güçlükler, hizmet öncesi eğitim yeterlikleri ve mesleğe adanmışlıkları. (Yayımlanmamış doktora tezi). Yüzüncü Yıl Üniversitesi, Van.

Milli Ĕ̆itim Bakanlığı (MEB). (2006). Öğretmenlik mesleği genel yeterlikleri. https://oygm.meb.gov.tr/meb_iys_dosyalar/2017_12/13161921_YYretmenlik _MesleYi_Genel_YETERLYKLERi_onaylanan.pdf adresinden 04.10.2019 tarihinde edinilmiştir.

Milli Ĕ̆itim Bakanlığı (MEB). (2017). Öğretmenlik mesleği genel yeterlikleri. http://oygm.meb.gov.tr/meb_iys_dosyalar/2017_12/11115355_YYRETMEN LYK_MESLEYY_GENEL_YETERLYKLERY.pdf adresinden 04.10.2019 tarihinde edinilmiştir.

Numanoğlu, G. ve Bayır, Ş. (2009). Bilgisayar öğretmen adaylarının öğretmenlik mesleği genel yeterliklerine ilişkin görüşleri. Ahi Evran Üniversitesi Kırşehir Eğitim Fakültesi Dergisi (KEFAD) 10(1), 197-212. 
Özbek, R., Kahyaoğlu, M. ve Özgen, N. (2007). Öğretmen adaylarının öğretmenlik mesleğine yönelik görüşlerinin değerlendirilmesi, Sosyal Bilimler Dergisi, 9(2), 222-233.

Özdemir, S. M., Ceylan, M. ve Canoğlu, S. N. (2015). To what extent can pre-service teachers turn theoretical knowledge they have acquired into practice? International Online Journal of Educational Sciences, 7(2), 265-282. https://doi.org/10.15345/iojes.2015.03.020

Özer, B. ve Gelen, İ. (2008). Öğretmenlik mesleği genel yeterliklerine sahip olma düzeyleri hakkında öğretmen adayları ve öğretmenlerin görüşlerinin değerlendirilmesi. Mustafa Kemal Üniversitesi Sosyal Bilimler Enstitüsü Dergisi, 5(9), 39-55.

Resmi Gazete. (2019). 1733 Sayılı Cumhurbaşkanı kararı. https://www.resmigazete.gov.tr/eskiler/2019/11/20191104M1-1.pdf adresinden 04.10.2019 tarihinde edinilmiştir.

Selvi, K. (2010). Teachers' competencies. Cultura. International Journal of Philosophy of Culture and Axiology, 7(1), 167-175. https://doi.org/10.5840/cultura20107133

Smith, T. D., and McMillan, B. F. (2001, April). Primer of model fit indices in structural equation modeling. Paper presented at the Annual Meeting of the Southwest Educational Research Association, New Orleans, LA, USA.

Taşar, H.H. (2012). İlköğretim okullarında çalışan öğretmenlerin mesleki yeterlik algılarının incelenmesi. Verimlilik Dergisi, 4, 67-77.

Taşgın, A. ve Sönmez, S. (2013). Öğretmenlik mesleği genel yeterliklerinin sınıf öğretmenleri ve sınıf öğretmeni adaylarının görüşlerine göre değerlendirilmesi. Middle Eastern and African Journal of Educational Research, 3, 80- 90.

Yalçın İncik, E. ve Akay, C. (2015). Eğitim fakültesi ve pedagojik formasyon sertifika programlarında öğrenim gören öğretmen adaylarının öğretmenlik mesleği genel yeterliklerine yönelik görüşleri. Ahi Evran Üniversitesi Kırşehir Eğitim Fakültesi Dergisi, 16(2), 179-197.

Yenen, E.T. ve Kılınç, H.H. (2018). Öğretmenlerin öğretmenlik mesleği genel yeterliklerine sahip olma düzeylerinin incelenmesi. Uluslararası Türkçe Edebiyat Kültür Eğitim Dergisi, 7(4), 2767-2787. https://doi.org/10.7884/teke.4325

Yeşilyurt, E. (2011). Öğretmen adaylarının öğretmenlik mesleğinin genel yeterliklerine yönelik yeterlik alg1ları. Türk Eğitim Bilimleri Dergisi, 9(1), 71-100.

Yıldırım, O. ve Koca, R. M. (2015). Fen, matematik alanlarından mezun ve 2013 KPSS'ye katılan adayların başarı durumlarının karşılaştırılması. Eğitim ve Öğretim Araştırmalar Dergisi, 4(4), 148-155.

YÖK (2018). Yeni öğretmen yetiştirme lisans programları. https://www.yok.gov.tr/kurumsal/idari-birimler/egitim-ogretimdairesi/yeni-ogretmen-yetistirme-lisans-programlari adresinden 15.11.2019 tarihinde erişilmiştir. 


\section{Summary}

\section{Introduction}

The competencies that individuals should possess in all areas of life vary according to the time period experienced. Especially in the 21st century, the intense changes and transformations affected the competencies that individuals should have. Schools and teachers are important dimensions in the process of gaining these competencies by individuals. From this aspect, it is clear that teachers need to have various competencies in order to make effective teaching. The Ministry of National Education (MoNE) (2017) defines teacher competencies as "the knowledge, skills and attitudes that teachers must have in order to fulfill their teaching profession effectively and efficiently". In 2008, special field competencies were determined in 14 areas for teachers at primary education level and in 2011 in eight areas for teachers at secondary education level. In line with these documents, General Competencies for Teaching Profession were updated in 2017. Within the scope of this study, general competencies of teaching profession consist of three proficiency fields: professional knowledge, professional skills and attitude and values components; 11 competencies and 65 indicators. It is important for the teachers to be aware of the professional competencies they have, and to determine the deficiencies based on this, and to ensure their personal development. In the general competencies of the teaching profession (MoNE, 2017), teachers are expected to plan their personal and professional development by making self-assessment of the competencies expected of them.

\section{Method}

This research was designed as a descriptive survey research. In this study, the data were collected from first and fourth grade teacher candidates studying at the education faculty of a public university and teachers working in different types of schools in the same province where the relevant public university is located. Convenience sampling was used in the selection of the participants. In order to collect data in the study, a measurement tool was developed using the indicators included in the general competencies of the teaching profession published by MoNE (2017). Relevant qualifications consist of 65 items related to indicators in the fields of professional knowledge, professional skills and attitudes and values. Validity and reliability studies of the created tool were carried out. The scales applied to teachers and students were analyzed separately. Item total correlations were examined for each measurement tool, confirmatory factor analyses were performed and reliability calculations were made.

\section{Results}

According to the findings of the research, teachers perceive their proficiency related to the profession at a high level. When the competence areas are analyzed, it has been determined that the teachers evaluate themselves positively in the field of "attitude and values" and this is followed by the "professional skill" field. Teachers perceive their competencies in the field of "professional knowledge" less than the other two fields. Prospective teachers perceive their competencies at a lower level than teachers. Prospective teachers also saw themselves as sufficient in the field of 
"attitude and values" at the highest level. This is followed by "professional skill" and "professional knowledge" competence areas.

According to another result of the study, when the averages of teachers and pre-service teachers were compared, a significant difference was found in favor of teachers in all sub-dimensions and across the scale, with the exception of "approach to students". Also, teachers' competency perceptions differ significantly by gender and seniority in some dimensions but not by major, school type or education level; pre-service teachers' competency perceptions do differ by gender but differ by grade level and department variables in some dimensions.

\section{Discussion}

Yenen and Kilınç (2018) found that teachers consider themselves sufficient in terms of professional knowledge, professional skills and attitudes and values. Göçmen (2014), Karamazoğlu and Arslan (2012), Taşar (2012), Eraslan Keskinkılıç (2010) and Karacaoğlu (2008) also found that teachers' perceptions of professional competence are positive. However, Çayak (2014) determined that elementary school teachers consider themselves sufficient to apply the constructivist approach. In their study, Çelik, Yorulmaz and Çokçaliskan (2019) found that teachers and teacher candidates evaluated themselves with a high average in terms of general competence of the teaching profession.

The difference in skills in favor of teachers may be related to the fact that the teaching profession develops with experience. This may be due to both the findings of pre-vocational teacher education not preparing the candidates sufficiently for the profession and the fact that the teaching profession is closely linked to the student group and the environment and conditions in which learning takes place and that it does not fully absorb without encountering real environments (Yenen and Kılınç, 2018).

\section{Pedagogical Implications}

Considering that these competencies are an important variable in teacher education and teaching process, it is clear that more studies are needed with current competencies in this regard. Among the limitations of this study, it can be stated that the study is only of a quantitative structure. There is a need for studies supported by qualitative data as well as quantitative studies with larger samples. In addition, the collection of data from different regions of Turkey will make the comparisons more meaningful. Regarding teacher competencies, it would be appropriate to refer to the opinions of administrators, students and parents.

\section{Araştırmanın Etik Taahhüt Metni ${ }^{i}$}

Yapılan bu çalışmada bilimsel, etik ve alıntı kurallarına uyulduğu; toplanan veriler üzerinde herhangi bir tahrifatın yapılmadığı, karşılaşılacak tüm etik ihlallerde "Cumhuriyet Uluslararası Eğitim Dergisi ve Editörünün" hiçbir sorumluluğunun olmadığı, tüm sorumluluğun Sorumlu Yazara ait olduğu ve bu çalışmanın herhangi başka bir akademik yayın ortamına değerlendirme için gönderilmemiş olduğu sorumlu yazar tarafından taahhüt edilmiştir.

Etik kurul izin bilgileri 
Etik değerlendirmeyi yapan kurul ad1 = Afyon Kocatepe Üniversitesi Sosyal ve Beşeri Bilimler Bilimsel Araştırma ve Yayın Etiği Kurulu

Etik değerlendirme kararının tarihi= 11.01.2019

Etik değerlendirme belgesi sayı numarası= 31731878-050.01.04

\section{Authors' Biodata/ Yazar Bilgileri}

Mehmet KOÇYİĞİT Afyon Kocatepe Üniversitesi Eğitim Fakültesi'nde Eğitim Yönetimi Anabilim dalında Dr. Öğr. Üyesi olarak görev yapmaktadır.

Mehmet Kocyigit works as an Asst. Prof. at Afyon Kocatepe University Faculty of Education, Department of Educational Administration.

Cahit ERDEM Afyon Kocatepe Üniversitesi Eğitim Fakültesi'nde İngiliz Dili Eğitimi Anabilim dalında Dr. Öğretim Üyesi olarak görev yapmaktadır.

Cahit Erdem works as an Asst. Prof. at Afyon Kocatepe University Faculty of Education, dapartment of English Language Teaching.

Eray EĞMíR Afyon Kocatepe Üniversitesi Eğitim Fakültesi'nde Eğitim Programları ve Öğretim Anabilim dalında Dr. Öğr. Üyesi olarak görev yapmaktadır.

Eray Egmir, works as an Asst. Prof. at Afyon Kocatepe University Faculty of Education, Department of Curriculum and Instruction.

\footnotetext{
i Bu çalışmanın etik açıdan bir sakınca taşımadığı Afyon Kocatepe Üniversitesi Sosyal ve Beşeri Bilimler Bilimsel Araştırma ve Yayın Etiği Kurulu'nun almıs olduğu 11.01.2019 tarih ve 31731878-050.01.04 sayılı karar ile tespit edilmiştir.
} 